\title{
Hormonal Regulation of Mammalian Adult Neurogenesis: A Multifaceted Mechanism
}

\author{
Claudia Jorgensen ${ }^{1, *}$ and Zuoxin Wang ${ }^{2}$ \\ 1 Behavioral Science Department, Utah Valley University, Orem, UT 84058, USA \\ 2 Psychology Department and Program in Neuroscience, Florida State University, Tallahassee, FL 32306, USA; \\ zwang@psy.fsu.edu \\ * Correspondence: cjorgensen@uvu.edu
}

Received: 28 June 2020; Accepted: 1 August 2020; Published: 6 August 2020

\begin{abstract}
Adult neurogenesis-resulting in adult-generated functioning, integrated neurons-is still one of the most captivating research areas of neuroplasticity. The addition of new neurons in adulthood follows a seemingly consistent multi-step process. These neurogenic stages include proliferation, differentiation, migration, maturation/survival, and integration of new neurons into the existing neuronal network. Most studies assessing the impact of exogenous (e.g., restraint stress) or endogenous (e.g., neurotrophins) factors on adult neurogenesis have focused on proliferation, survival, and neuronal differentiation. This review will discuss the multifaceted impact of hormones on these various stages of adult neurogenesis. Specifically, we will review the evidence for hormonal facilitation (via gonadal hormones), inhibition (via glucocorticoids), and neuroprotection (via recruitment of other neurochemicals such as neurotrophin and neuromodulators) on newly adult-generated neurons in the mammalian brain.
\end{abstract}

Keywords: adult neurogenesis; hormones; hippocampus; dentate gyrus

\section{Introduction}

Adult neurogenesis, resulting in adult-generated functioning neurons, is still one of the most captivating research areas of neuroplasticity. While the first accounts were met with decades of skepticism, methodological advances_-including the introduction of the synthetic thymidine analog 5-bromo-3'-deoxyuridine (BrdU) and the use of cell-type specific markers-helped to establish neurogenesis in adult rodents [1,2]. Adult-generated neurons have also been found in numerous other species, including marmosets [3,4], macaques [5], opossums (Monodelphis domestica) [6], and even humans [7,8]. Ultimately, adult neurogenesis was accepted as a real phenomenon and has since been observed in almost all mammals examined so far [9,10], but see [11].

Adult-generated neurons have been most commonly observed in the hippocampus and the main olfactory bulb (MOB, see Figure 1). Specifically, cells generated in the subgranular zone (SGZ) migrate to the granular cell layer (GCL) of the dentate gyrus (DG) of the hippocampus where many mature into functional granule cells $[12,13]$. Cells generated in the subventricular zone (SVZ) of the lateral ventricles migrate along the rostral migratory stream (rms) to mature into interneurons in the MOB [13-15]. Adult neurogenesis has also been documented in other brain regions such as the amygdala (AMY) [16-19], bed nucleus of the stria terminalis [18], hypothalamus (HYP) [17,19-21], medial preoptic area (MPOA) [18], neocortex [22-24], piriform cortex [16], and the striatum [18,22,25]. 


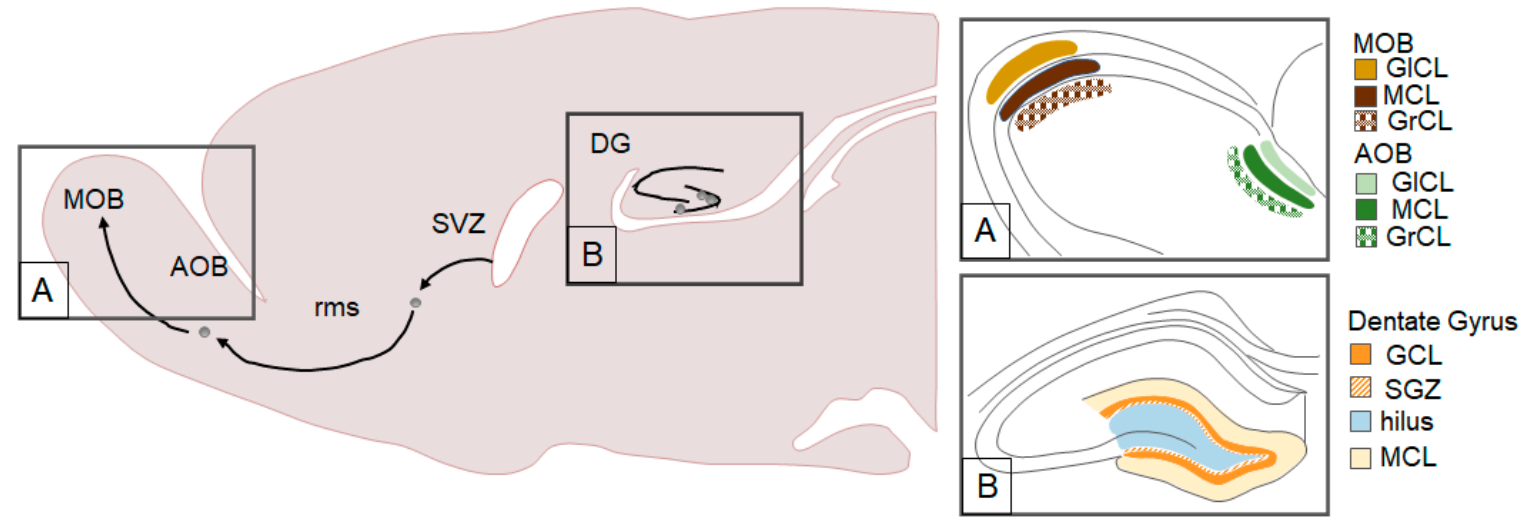

Figure 1. Traditional neurogenic brain regions including the subventricular zone (SVZ) system and the dentate gyrus (DG) of the hippocampus. A. Cells generated in the SVZ migrate along the rostral migratory stream (rms), pass the accessory olfactory bulb (AOB), and reach the main olfactory bulb (MOB). The MOB and AOB have the following three layers: glomerular cell layer (GlCL), molecular cell layer (MCL), and the granular cell layer (GrCL). B. The DG has various components including the granular cell layer (GCL), subgranular zone (SGZ), hilus, and molecular cell layer (MCL).

The addition of new neurons in adulthood-regardless of species or brain region-follows a seemingly consistent and complex multi-step process [26,27]. Briefly, these neurogenic stages include proliferation, differentiation, migration, maturation/survival, and integration into the existing neuronal network (for more detail see [9]). Proliferation refers to the birth of new cells, which then undergo glial or neuronal fate specification [28]. The birth of new cells is commonly assessed using endogenous markers (such as Ki67) or exogenous markers (such as 5-bromo-3'-deoxyuridine, BrdU, or tritiated thymidine combined with a survival time of 2-24 h) [26,29-35]. Cells that have undergone neuronal differentiation express morphological characteristics of neurons as well as neuronal markers (such as doublecortin, Dcx; neuron-specific class III $\beta$-tubulin; and NeuN) [36-38]. Following migration to a specific brain region, immature neurons develop dendrites and an axon-steps necessary to the survival of the neuron. Survival of adult-generated cells can be investigated by BrdU injection and perfusion any time after $25 \mathrm{~h}$ [28]. Lastly, the adult-generated neuron forms synapses to allow connections with the surrounding neuronal network $[23,39]$. Adult-generated neurons that fail to integrate into the existing neuronal network are eliminated by apoptosis (assessed by apoptotic markers or pyknotic morphology) [40-42]. Evidence suggests that cell birth and cell death in adulthood, as observed during development, are closely coordinated events [42-44].

Numerous exogenous (e.g., voluntary exercise and exposure to environmental enrichment) and endogenous (e.g., hormones and neurotrophins) factors influence these different neurogenic stages [13,45-47]. Specifically, a factor influencing cell proliferation either up- or down-regulates the birth of new cells, while a factor influencing survival promotes or prevents differentiation, maturation, and/or integration. Interestingly, the individual neurogenic stages might be influenced independently of one another. As such, cell proliferation can be up-regulated without influencing the other stages or cell survival might be down-regulated without altering other stages. Therefore, it is essential to investigate the impact of exogenous and endogenous factors on each of the neurogenic stages. While numerous reviews have discussed the impact of hormones such as gonadal steroids [48-54] and glucocorticoids [49,55-57] on adult neurogenesis, the following review will highlight the multifaceted impact of hormones on the various stages of mammalian adult neurogenesis. This is a fairly unique approach that to our knowledge has rarely been used. Specifically, we will discuss hormonal facilitation (via gonadal steroids), inhibition (via glucocorticoids), and neuroprotection (via the recruitment of the brain-derived neurotrophic factor, BDNF, and the neuromodulators serotonin, 5-HT, and oxytocin, OT) of mammalian adult neurogenesis. The impact specifically on the various neurogenic stages will be 
reviewed in the DG and the SVZ/MOB system, but nontraditional neurogenic brain regions will also be discussed.

\section{Hormonal Facilitation of Adult Neurogenesis}

Various factors have been shown to facilitate adult neurogenesis altering the different neurogenic stages (including cell proliferation, cell survival, and neuronal differentiation) independently from one another $[13,45,46]$. For example, voluntary exercise increased DG cell proliferation and survival, whereas exposure to an enriched environment only increased DG cell survival [58]. Therefore, it is essential to investigate the impact of any neurogenic factor on each stage of neurogenesis separately. Most studies on gonadal steroid regulation of adult neurogenesis have focused on androgens (e.g., testosterone and dihydrotestosterone (DHT)) and estrogens (e.g., estradiol, estrone, and estriol), thus we will discuss the evidence of these hormones acting as neurogenic factors in the adult mammalian brain-highlighting the specific stages of adult neurogenesis that can be impacted.

\subsection{Androgens}

Androgens are hormones that influence male reproductive activity; play a role in social behavior, cognition, and mood; and are potent regulators of neural plasticity [59-63]. Here, we will discuss the evidence that neurogenic stages might be affected by the natural fluctuations of androgens and by manipulations of the androgen system (namely castration, TX, the bilateral removal of testes) and androgen replacement.

\subsubsection{Natural Fluctuations of Androgens}

Mammals commonly display seasonal reproduction, which is associated with variations in blood androgen levels [64-67]. The seasonally reproductive meadow vole (Microtus pennsylvanicus) displays a photoperiod-dependent reproductive status - with exposure to a long photoperiod resulting in larger testicular weight and higher blood androgen levels [68,69]. Consequently, male meadow voles that display high androgen levels during the breeding season (long photoperiod) and low androgen levels during the non-breeding season (short photoperiod) have been used as a model to study the impact of seasonally fluctuating androgen on adult neurogenesis. One such study found that cell proliferation in the hilus, but not GCL, was higher in wild-living meadow voles captured during the breeding compared to the non-breeding season [70]. No other neurogenic stages were investigated. A subsequent study [41] aimed to address factors (such as age, previous experience, and capture-induced stress response) that may function as potent regulators of adult neurogenesis [71-74] and cannot easily be controlled in a wild sample [70]. To assess hippocampal cell proliferation and survival, laboratory-reared meadow voles were acclimated to a long or short photoperiod to simulate the breeding or non-breeding season, respectively [41]. Higher DG cell survival, but not proliferation, was found in reproductively-active versus -inactive males. As laboratory-reared voles likely lack the same complex demands as wild-living voles, another study used endogenous adult neurogenesis markers-eliminating the need for captivity-in wild-living meadow voles to assess DG neurogenesis [69]. In this study, reproductively-active males displayed less cell proliferation and neuronal differentiation in the GCL and SGZ than reproductively-inactive voles. It is important to mention that this study was solely correlational (with many uncontrolled variables such as age or the heightened glucocorticoid levels during the breeding season). Therefore, future studies should verify the relationship of androgens on all neurogenic stages experimentally. Collectively, the findings from these studies suggest that prolonged exposure to high circulating androgen levels during the breeding season inhibit cell proliferation but enhance cell survival in meadow voles (see Table 1). 
Table 1. The effects of androgens on the different stages of adult neurogenesis in several mammalian species.

\begin{tabular}{|c|c|c|c|c|c|c|}
\hline & & Species & Cell proliferation & Cell Survival & Neuronal Differentiation & References \\
\hline \multicolumn{7}{|c|}{ NATURAL INCREASE } \\
\hline \multirow{2}{*}{\multicolumn{2}{|c|}{ Breeding season }} & wild-living o ${ }^{\top} \mathrm{MV}$ & $\leftrightarrow \mathrm{GCL}+\mathrm{SGZ}$ & - & $\downarrow \mathrm{GCL}+\mathrm{SGZ}$ & {$[69,70]$} \\
\hline & & lab-reared $0^{x} \mathrm{MV}$ & $0 \mathrm{GCL}+\mathrm{SGZ}$ & $\uparrow \mathrm{GCL}+\mathrm{SGZ}$ & - & [41] \\
\hline \multirow{5}{*}{ Sexual experience } & \multirow{2}{*}{ Acute (One encounter) } & $\begin{array}{c}0^{\lambda} \text { rat } \\
\text { (young \& middle-aged) }\end{array}$ & $\begin{array}{l}\uparrow \mathrm{DG} \\
0 \mathrm{SVZ}\end{array}$ & $\begin{array}{l}\uparrow \mathrm{AOB} \\
0 \mathrm{MOB}\end{array}$ & 0 АОВ & [75-78] \\
\hline & & $\sigma^{\top}$ mouse & - & $0 \mathrm{AOB}, \mathrm{MOB}$ & $\begin{array}{l}0 \mathrm{AOB} \\
\uparrow \mathrm{MOB}\end{array}$ & [79] \\
\hline & \multirow{3}{*}{ Chronic (Daily or weekly encounter 14 days) } & $\begin{array}{c}\sigma^{r} \text { rat } \\
\text { (young \& middle-aged) }\end{array}$ & $\uparrow \mathrm{DG}$ & $\uparrow \mathrm{DG}$ & $0 \mathrm{DG}$ & {$[75,76]$} \\
\hline & & $\sigma^{7}$ mouse & - & $\uparrow \mathrm{DG}$ & $0 \mathrm{DG}$ & [80] \\
\hline & & $\sigma^{x}$ hamster & $0 \mathrm{MeP}, \mathrm{MPOA}$ & $0 \mathrm{MeP}, \mathrm{MPOA}$ & - & [15] \\
\hline & & DECREASE VIA TX & & & & \\
\hline & Short-term TX (7 days) & $o^{x^{3}}$ rat & $0 \mathrm{GCL}$ & - & - & [81] \\
\hline \multirow{3}{*}{\multicolumn{2}{|c|}{ Long-term TX (>14 days) }} & $o^{3}$ rat & $\downarrow \mathrm{GCL}+\mathrm{SGZ}$ & $\downarrow \mathrm{GCL}, \mathrm{GCL}+\mathrm{SGZ}$ & $0 \mathrm{GCL}+\mathrm{SGZ}$ & [81-83] \\
\hline & & $\sigma^{7}$ mouse & $0 \mathrm{DG}$ & - & $\leftrightarrow \mathrm{GCL}$ & {$[84,85]$} \\
\hline & & $o^{x}$ hamster & $\begin{array}{l}\downarrow \mathrm{MeP} \\
0 \mathrm{MPOA}\end{array}$ & 0 AMY, MPOA & - & [15] \\
\hline \multicolumn{7}{|c|}{ TX AND ANDROGEN REPLACEMENT } \\
\hline \multirow{2}{*}{ Short-term replacement ( $\leq 5$ days) } & Testosterone proprionate $(0.1 \mathrm{mg} / \mu \mathrm{L}, 20 \mu \mathrm{L} /$ pellet $)$ & $\sigma^{\top} \mathrm{MV}$ & $\begin{array}{c}\uparrow \mathrm{CoA}, \mathrm{MeA} \\
0 \mathrm{CeA}, \mathrm{DG}, \mathrm{HYP}\end{array}$ & - & 0 AMY & [86] \\
\hline & DHT $(0.1 \mathrm{mg} / \mu \mathrm{L}, 20 \mu \mathrm{L} /$ pellet $)$ & $\mathrm{o}^{\mathrm{M} M V}$ & 0 AMY, DG, HYP & - & 0 AMY & [86] \\
\hline \multirow{5}{*}{ Long-term replacement (>14 days) } & Testosterone proprionate (30-day: $0.25 \mathrm{mg} / 0.1 \mathrm{~mL}$ or $100 \mathrm{mg} /$ pellet) & $o^{3}$ rat & $0 \mathrm{GCL}$ & $0 \mathrm{GCL}$ & $0 \mathrm{GCL}$ & {$[81,88]$} \\
\hline & Testosterone proprionate (29-day: 0.5 or $1.0 \mathrm{mg} / 0.1 \mathrm{~mL}$ ) & $o^{\top}$ rat & - & $\uparrow \mathrm{GCL}$ & $0 \mathrm{GCL}$ & [81] \\
\hline & Testosterone proprionate (15- or 21 -day: 0.5 or $1 \mathrm{mg} / 0.1 \mathrm{~mL}$ ) & $o^{3}$ rat & $0 \mathrm{GCL}$ & $0 \mathrm{GCL}$ & - & {$[83,89]$} \\
\hline & $\begin{array}{l}\text { 17ß-estradiol ( } 0.01 \text { or } 0.02 \mathrm{mg} / 0.1 \mathrm{~mL}) \\
\text { Estradiol benzoate }(15 \mu \mathrm{g} / \text { inj.) }\end{array}$ & $o^{7}$ rat & $0 \mathrm{GCL}$ & $0 \mathrm{GCL}$ & $0 \mathrm{GCL}$ & {$[81,90]$} \\
\hline & DHT (30-day: 0.25 and $0.5 \mathrm{mg} / 0.1 \mathrm{~mL}$ ) & $\begin{array}{c}\sigma^{\lambda} \text { rat } \\
\text { (young \& middle-aged) }\end{array}$ & - & $\uparrow \mathrm{GCL}$ & $0 \mathrm{GCL}$ & {$[81,91]$} \\
\hline
\end{tabular}

Abbreviations used: AMY, amygdala; AOB, accessory olfactory bulb; DG, dentate gyrus; CeA, central AMY; CoA, cortical AMY; diff, differentiation; DHT, dihydrotestosterone; GCL, granular cell layer in the dentate gyrus; HYP, hypothalamus; MeA, medial AMY; MeP, posterior medial AMY; MOB, main olfactory bulb; MPOA, medial preoptic area; MV, meadow vole; SGZ, subgranular zone in the dentate gyrus; SVZ, subventricular zone; $\uparrow$ : increase; $\downarrow$ : decrease; 0 : no change; $\leftrightarrow$ : mixed findings; -: no data; $\sigma^{\star}$ : male. 
Blood androgen levels also change due to sexual experience-increasing before, during, and following sexual activity, which, in turn, can impact adult neurogenesis [92-95]. Indeed, one acute mating encounter increased DG, but not SVZ, cell proliferation in male Sprague-Dawley rats and cell survival in the accessory olfactory bulb (AOB), but not $\mathrm{MOB}$, of male Wistar rats without altering neuronal differentiation [75-78]. Interestingly, one acute mating encounter in male C57BL mice did not alter cell survival in the $\mathrm{AOB}$ or $\mathrm{MOB}$, but it increased neuronal differentiation in the glomerular cell layer of the MOB [79]—suggesting a potential species difference. Alternatively, methodological differences might explain the contrasting findings (sexually experienced rats [77] versus sexually naïve mice [79]).

Chronic mating exposure increased DG cell proliferation and survival in male Sprague-Dawley rats $[75,76]$ as well as DG cell survival in male CD1 mice [80] without altering neuronal differentiation. The majority of these DG-generated cells displayed a neuronal phenotype $[75,76,80]$. It is noteworthy that this upregulation of adult neurogenesis occurred even though the initial mating-induced testosterone peak had returned to baseline [75]—supporting a previously observed dissociation between sexual behavior and circulating testosterone levels [96]. In contrast, chronic mating exposure did not alter adult neurogenesis in the mating circuitry of male Syrian hamsters (Mesocricetus auratus) [15]. It is not clear at this time whether these contradictory findings between the DG and the mating circuitry reflect differences in methodology (daily versus weekly mating exposure), species (rat and mouse versus hamster), or brain region (DG versus mating circuitry).

Taken together, the above-mentioned studies suggest that fluctuating androgen levels impact adult neurogenesis in a neurogenic stage-specific manner. Higher androgen levels facilitate hippocampal adult neurogenesis, particularly cell survival, but not proliferation or neuronal differentiation. The impact of androgens on adult neurogenesis is also brain region-specific, as androgens did not alter adult neurogenesis in the SVZ or in the mating circuitry.

\subsubsection{Castration (TX)}

TX reduces circulating androgen levels profoundly, and TX is accompanied by the loss of mating behavior [97,98]. Only one study to our knowledge has examined the impact of short-term castration on DG adult neurogenesis [81]—showing that GCL and hilar cell proliferation was not altered following TX in Sprague-Dawley rats.

In contrast, long-term TX reduced cell proliferation in the GCL and SGZ, but not hilus, in male Sprague-Dawley rats [82]. Similarly to the DG, cell proliferation in the mating circuit of male Syrian hamsters was reduced following long-term TX [15]. Interestingly, long-term TX did not alter DG cell proliferation in male BALB/c and C57BL/6J mice [84,85]—suggesting a possible species difference. In addition, long-term TX also reduced cell survival in the GCL and SGZ in male Sprague-Dawley rats [81-83]. However, long-term TX did not alter cell survival in the hilus of male Sprague-Dawley rats or the mating circuit of male Syrian hamsters [15,81]—suggesting that the effect might be brain region-specific. Furthermore, neuronal differentiation seems to display a species-specific regulation. Namely, long-term TX did not alter neuronal differentiation in the hippocampus of male Sprague-Dawley rats or BALB/c mice but decreased neuronal differentiation in male C57BL/6J mice [82-85]

Together, these data suggest that long-, but not short-term, castration negatively impact adult neurogenesis, and this effect appears to be brain region-, species-, and neurogenic stage-specific (see Table 1).

\subsubsection{TX and Replacement with Androgen}

Following TX, androgen replacement commonly occurs via two types of androgens (testosterone and testosterone propionate) or via testosterone metabolites $5 \alpha$-dihydrotestosterone (DHT) and estradiol [99]. Short-term androgen replacement increased cell proliferation in the cortical and medial AMY of male meadow voles without altering the number of adult-generated cells in the central AMY, 
DG, or HYP or AMY neuronal differentiation [86]. Interestingly, DG cell survival depended on the time point of estrogen benzoate replacement (see Table 1) [87].

Long-term androgen replacement increased survival in the GCL, but not hilus, in male Sprague-Dawley rats without altering GCL neuronal differentiation [81,90]—suggesting a brain region-specific effect. The effect of testosterone replacement also appears to be dose-dependent. While testosterone doses of 0.5 and $1 \mathrm{mg}$ (resulting in hyperphysiological levels) increased GCL survival, a low $(0.25 \mathrm{mg}$, resulting in a level similar to gonad-intact males) or high (100 mg/pellet) dose failed to alter GCL proliferation and survival $[81,88]$. Additional support for the dose-dependent effect comes from in-vitro studies [100,101]—showing enhanced neurite outgrowth with lower testosterone concentrations and apoptosis with higher concentrations. The length of hormonal replacement also seems to matter, as only 30-day, but not 15- or 21-day, treatment increased DG cell survival in male Sprague-Dawley rats $[83,89]$. TX slowly leads to the complete elimination of sexual behavior and testosterone replacement only leads to the full recovery of mating after 8 weeks [97,102]—providing support for the long-term impact of hormonal replacement.

Long-term estradiol treatment did not promote DG neurogenesis in male castrated rats [81,90]. Long-term DHT increased GCL, but not hilus, cell survival in male Sprague-Dawley rats without altering neuronal differentiation [81]. Interestingly, this increase was not observed in middle-aged (11-12 month-old) Sprague-Dawley rats [91]. Finally, DHT treatment in rats pre-treated with an androgen receptor antagonist failed to show the DHT-induced hippocampal adult neurogenesis [103]. Therefore, the negative impact of TX on adult hippocampal neurogenesis can be reversed by long-term androgen replacement via activation of androgen receptors (see Table 1).

\subsection{Estrogens}

Estrogens are hormones that influence motivated behaviors and various cognitive functions $[60,104,105]$. They are also potent regulators of neural plasticity, play a role in neuronal excitability, and are involved in synaptogenesis via dendritic spine synapse formation [104,106,107]. Here, we will discuss the evidence that neurogenic stages might be affected by the natural fluctuations of estrogens and by manipulations of the estrogen system (namely ovariectomy, OVX, the bilateral removal of ovaries) and estrogen replacement.

\subsubsection{Natural Cyclic Fluctuations of Estrogen}

Estrogen levels fluctuate significantly across the female estrous cycle. During diestrus, the $17 \beta$-estrogen level increases gradually, rises to its maximum level in proestrus, and subsequently decreases and reaches its lowest level near the end of estrus [108]. Using the female Sprague-Dawley rat, a spontaneous ovulator that displays a continuous cycling of reproductive hormones, researchers found that rats injected with BrdU during proestrus (highest estrogen levels) displayed higher DG, but not SVZ, cell proliferation than females injected during other phases of the estrous cycle [109]. Interestingly, such alterations in DG cell proliferation across the estrous cycle were not observed in female C57BL/6 or BALB/c mice $[85,110]$-suggesting a possible species difference between mice and rats (see Table 2). Cyclic estrogen levels also affect DG cell survival (assessed 4, 7, 14, and 21 days following BrdU injection)—female Sprague-Dawley rats showed higher DG cell survival during proestrus than estrus $[109,111]$. This difference remained until 21 days, at which point the difference in DG cell survival across proestrus and estrus was no longer present. It was noted that the majority of adult-generated cells were neurons and neuronal differentiation was not altered [109,111]. 
Table 2. Effects of estrogens on the different stages of adult neurogenesis in several mammalian species.

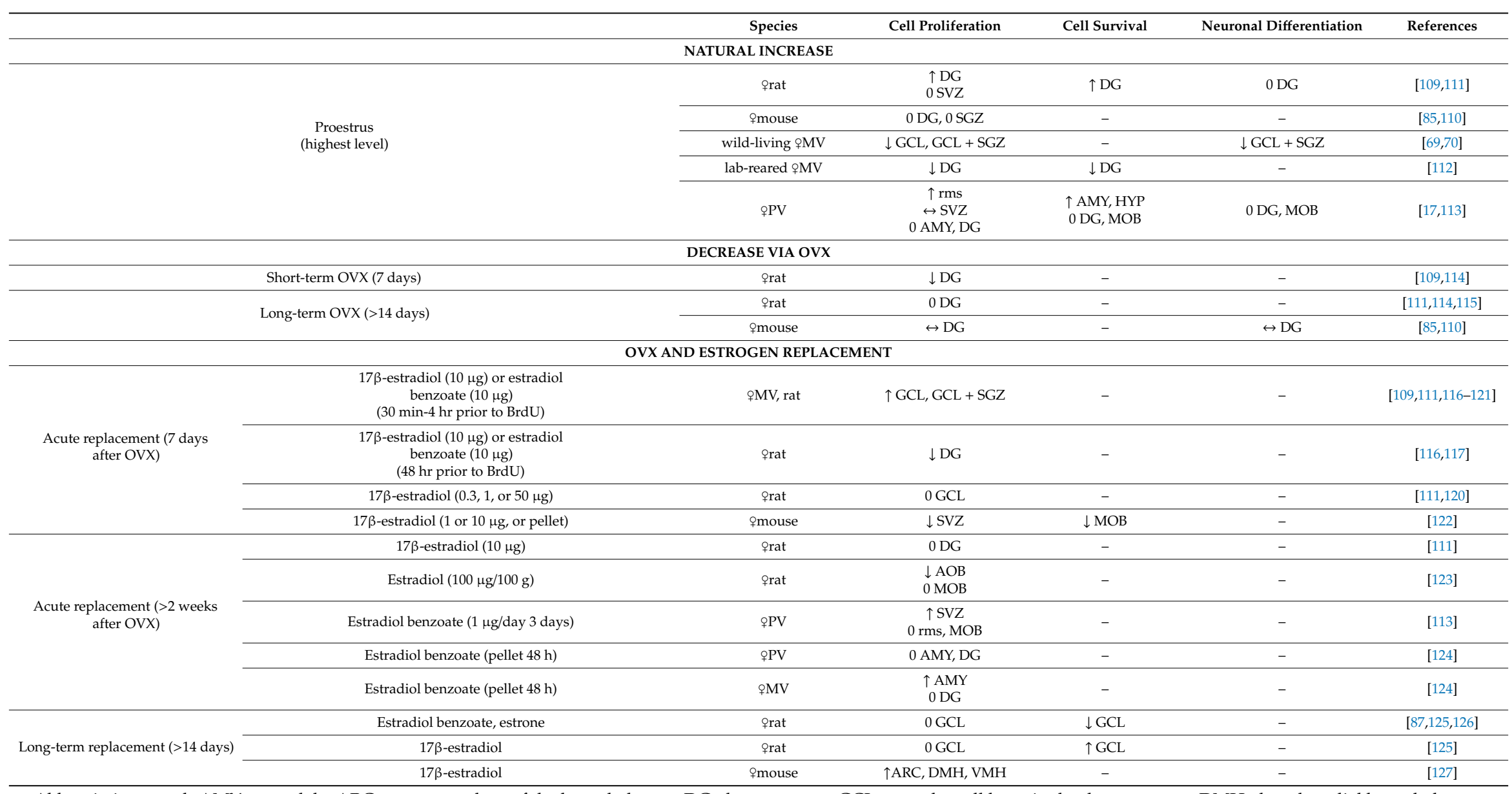

Abbreviations used: AMY, amygdala; ARC, arcuate nucleus of the hypothalamus; DG, dentate gyrus; GCL, granular cell layer in the dentate gyrus; DMH, dorsal medial hypothalamus; HYP, hypothalamus; MOB, main olfactory bulb; MV, meadow vole; PV, prairie vole; rms, rostral migratory stream; SGZ, subgranular zone in the dentate gyrus; SVZ, subventricular zone of

the lateral ventricles; $\mathrm{VMH}$, ventromedial hypothalamus; $\uparrow$ : increase; $\downarrow$ : decrease; 0 : no change; $\leftrightarrow$ : mixed findings; -: no data; $\$$ : female. 
Unlike female rats or mice, female meadow and prairie voles are induced ovulators, in which the exposure to a male or male pheromones elicits behavioral estrous [128-130]. It is of interest to note that meadow and prairie voles (Microtus ochrogaster) display remarkable differences in social behaviors and life strategy. Meadow voles are promiscuous [131], whereas prairie voles are socially monogamous and form lasting pair-bonds [132]. In the wild, female voles have low blood estrogen levels during the non-breeding season, but once primed, their blood estrogen levels remain elevated throughout the breeding season [133]. Researchers captured wild-living female meadow voles across breeding seasons and contrary to findings in mice and rats found that reproductively-active females displayed lower GCL and hilus cell proliferation than reproductively-inactive females [70]. A possible explanation for the discrepancy in findings between mice/rats and meadow voles might be the differences in the ovulation onset-spontaneous versus induced ovulation. Alternatively, captive housing of wild-living meadow voles might have introduced confounding variables Using endogenous markers to eliminate the need for captive housing (a potential confound), researchers observed that reproductively-active females showed lower cell proliferation and neuronal differentiation in the GCL and SGZ than reproductively-inactive females [69]. Other confounding variables might include age, previous experience, and pregnancy status-as all wild-captured female meadow voles during the breeding season were pregnant. Not surprisingly, pregnancy (which is characterized by dramatic fluctuations in steroid hormones [134]) and age (which is associated with changes in circulating 17 $\beta$-estradiol levels [135]) have previously been identified as potent modulators of adult neurogenesis [71-73,136,137]. To address these confounding variables, researchers used laboratory-reared meadow voles and exposed them to a male (to induce behavioral estrous) or female conspecific (control) [112]. Male-exposed females were considered reproductively-active, conversely female-exposed females were considered reproductively-inactive. Reproductively-active females displayed lower GCL cell proliferation and survival than reproductively-inactive females. When the rates of adult-generated cells were compared between the proliferation and survival time points, the data indicate that high estrogen levels might have enhanced cell survival.

Using female prairie voles, researchers found that primed (via short-term male pheromone exposure) females displayed an increase in cell proliferation in the SVZ and along the rms [113]. Interestingly, in another study short-term male exposure did not alter cell proliferation in the SVZ, AMY, caudate putamen, cingulate cortex, DG, or HYP [17]. These contradictory findings between the two studies $[17,113]$ might be due to methodological differences including the type of exposure and the type of control group used. Specifically, one study [113] used a fine wire mesh that resulted in animals being able to see, smell, and have limited physical contact with, while preventing mating. The animals in the other study [17] were housed in the same cage allowing unrestricted social interaction including mating behavior. Long-term male exposure (allowing unrestricted social interaction) increased cell survival in the AMY and HYP but not caudate putamen, cingulate cortex, DG, or MOB of female prairie voles [17]. In the DG and SVZ/MOB, the majority of adult-generated cells expressed a neuronal phenotype. There were no group differences in neuronal differentiation.

Taking together, these studies suggest that fluctuating estrogen levels impact adult neurogenesis in a species-specific manner (see Table 2). In some species (e.g., rat and prairie vole) high estrogen levels are associated with a facilitation of adult neurogenesis. In other species (e.g., meadow vole and mouse) high estrogen levels are linked to a reduction or no alteration of cell proliferation and survival.

\subsubsection{Ovariectomy (OVX)}

OVX reduces circulating estrogen levels [107] as well as the number of estrogen receptors (ER; beta, but not alpha) [138]. Short-term OVX caused a drastic reduction in DG cell proliferation in female Sprague-Dawley and Wistar rats $[109,114]$, whereas long-term OVX did not alter DG cell proliferation in female Sprague-Dawley, Wistar, and Long-Evans rats [111,114,115]. Long-term OVX did not alter DG cell proliferation or neuronal differentiation in C57BL/6 mice [110]. Interestingly, in a different mouse strain, BALB/c, long-term OVX reduced cell proliferation and neuronal differentiation [85]. 
To summarize, short-term depletion of estrogen negatively impacts DG adult neurogenesis, while long-term depletion might have a species-specific impact (see Table 2). This time-dependent manner of OVX on adult neurogenesis mirrors the results of OVX on hippocampal dendritic spine density [107]. Specifically, spine density decreases gradually for the 6 days following OVX. No further decrease is observed up to 40 days following OVX.

\subsubsection{OVX and Replacement with Estrogen}

Following OVX, estrogen replacement might occur via three main forms of estrogen, namely estrone (E1), estradiol (E2, which includes the optical isomers $17 \beta$-estradiol and $17 \alpha$-estradiol), and estriol (E3). The vast majority of studies examining neuroplasticity have used estradiol and its analog estradiol benzoate, as it is the most prevalent and potent form of estrogen [108,125].

Short-term estrogen replacement increased DG cell proliferation in female Sprague-Dawley rats and meadow voles - thereby reversing the OVX-induced reduction in cell proliferation [109,111,116-121]. Similarly, short-term estrogen replacement increased cell proliferation in the prairie vole SVZ, but not the rms or MOB [113] - suggesting a potential brain region-specific effect. Interestingly, estradiol replacement in female C57BL6/J mice led to a decrease in SVZ cell proliferation [122]—suggesting a potential species-specific effect. Alternatively, this difference might be due to species differences in baseline hormonal levels. Voles, which are induced ovulators, exhibit consistently high levels of circulating estrogen during the breeding season (20-30 days), while rats and mice exhibit high estrogen fluctuations across a 4-day estrous cycle [49]. Therefore, estrogen treatment does not cause highly unnatural hormonal levels in voles.

The effects of estrogen replacement also seem dose-specific as a $10 \mu \mathrm{g}$ dose (that results in circulating estrogen levels in the proestrus range $[139,140]$ ) increased whereas other doses (such as 0.3 , 1 , or $50 \mu \mathrm{g})$ did not alter DG cell proliferation and a high dose $(100 \mu \mathrm{g} / 100 \mathrm{~g}$ body weight) reduced cell proliferation in the AOB $[111,120,123]$. It is noteworthy to understand that dose and type of estrogen are related factors - as one dose might be effective for one type of estrogen while ineffective for another type of estrogen [120]. Underlying pharmacokinetic and pharmacological differences between the different types of estrogen might be causing these differences [108]. For example, the administration of estrogen esters yields different peak estradiol levels-higher levels following estradiol valerate and benzoate treatment than estradiol cypionate treatment [141]. In addition, the impact of estrogen replacement also appears time-specific. On one hand, the estrogen-induced reversal of OVX-induced reduction in cell proliferation is transient-short-term (30 min or $4 \mathrm{~h}$ ) estrogen replacement increases whereas long-term $(48 \mathrm{~h})$ estrogen replacement decreases hippocampal cell proliferation [116,117]. On the other hand, latency of estrogen replacement following OVX seems to matter. Following brief latency (1 week) estrogen replacement increased, whereas long latency (28 or more days) does not alter hippocampal cell proliferation [111,124].

Long-term estrogen treatment did not alter hippocampal cell proliferation in female and male rats [90,111,125,126] — regardless of estrogen-type, dose, or sex. Interestingly, long-term estrogen replacement altered hippocampal cell survival in a sex-specific manner. Namely, hippocampal cell survival was not altered in males but reduced in females $[90,126]$. Interestingly, the impact on cell survival might be estrogen type-specific. Long-term treatment with estradiol benzoate and estrone reduced hippocampal cell survival, whereas $17 \beta$-estradiol treatment increased hippocampal cell survival in female rats $[90,125,126]$. It is worth mentioning that another study (using 17 $\beta$-estradiol) found an increase in cell survival in the $\mathrm{VMH}$, arcuate nucleus of the hypothalamus, and the dorsal medial hypothalamus of mice following chronic estrogen treatment [127]. At the moment, it is not known whether this finding indicates a brain region-, species-, or estrogen type-specific impact.

To summarize, estrogen impacts cell proliferation in a dose-, estrogen-type-, time-, and brain region-specific manner (see Table 2). There is also a species-specific effect-for example data showing that estrogen replacement increased AMY cell proliferation in the promiscuous meadow voles but did not alter AMY cell proliferation in the pair-bonding prairie vole [124]. However, it should be 
noted that the various methodological approaches across studies make it difficult to derive patterns or conclusions with certainty. It cannot be ruled out that methodological differences (e.g., type of estrogen, subjects' ages, and estrogen dosages) might also have influenced the alterations in adult neurogenesis.

\section{Hormonal Inhibition of Adult Neurogenesis}

Exposure to stressors, such as predation, is a ubiquitous part of the animal kingdom and commonly triggers a stress response. In turn, the stress response causes the activation of the hypothalamic-pituitary-adrenal (HPA) axis, leading to increased glucocorticoids release [89]. These steroid hormones (corticosterone in rodents and cortisol in humans) seem to play an important role in neuroplasticity-especially in limbic brain regions. In the DG, high glucocorticoid levels suppress long-term potentiation [142], cause dendritic atrophy [143-146], and can result in neuronal loss $[142,144,145,147]$. High glucocorticoid levels alter spine density in the AMY and cause cell loss in the prefrontal cortex [148-152]. Furthermore, steroid hormones also influence adult mammalian neurogenesis [57,153]. Glucocorticoid administration reduces DG cell proliferation and survival in male and female rats [154-158] as well as DG cell proliferation in male mice [159]. Similarly, the administration of a glucocorticoid receptor agonist, reduces DG cell proliferation [160]. On the contrary, adrenalectomy, which results in the removal of circulating glucocorticoids, leads to an increase in DG adult neurogenesis [161-163] and eliminates the stress-induced suppression of DG cell proliferation [164]. Other means of HPA axis inhibition reverse the stress-induced suppression of DG adult neurogenesis in male mice and rats [165-167]. The following section will discuss the impact of stressors that are associated with glucocorticoid release on cell proliferation, cell survival, and neuronal differentiation.

\subsection{Hormonal Inhibition of Cell Proliferation}

Exposure to various acute laboratory-specific as well as ethologically-relevant stressors reduced DG cell proliferation in numerous species, without altering SVZ cell proliferation [4,164,168-177]—suggesting a potential brain region-specific regulation (see Table 3 for detail).

Table 3. The effects of stressors on cell proliferation in several mammalian species.

\begin{tabular}{|c|c|c|c|c|}
\hline & Stressor & Species & Impact & References \\
\hline \multicolumn{5}{|c|}{ ACUTE (same day) } \\
\hline Laboratory stressors & $\begin{array}{l}\text { cold swim, foot shock, restraint, } \\
\text { tail nick, tail shock }\end{array}$ & $\begin{array}{l}\text { BALB/c mouse, Sprague-Dawley, wild } \\
\text { house mouse, Wistar rat }\end{array}$ & $\downarrow$ DG & {$[168-173,178,179]$} \\
\hline $\begin{array}{l}\text { Ethologically-relevant } \\
\text { stressors }\end{array}$ & predator odor, social defeat & $\begin{array}{c}\text { common marmoset (Callithrix jacchus), } \\
\text { Sprague-Dawley rat, tree shrew } \\
\text { (Tupaia belangeri) }\end{array}$ & $\downarrow \mathrm{DG}$ & {$[4,164,175-177]$} \\
\hline Brain region-specific & Foot shock + restraint & $\mathrm{BALB} / \mathrm{c}$ & $\begin{array}{l}\downarrow \mathrm{DG} \\
0 \mathrm{SVZ}\end{array}$ & [168] \\
\hline Sex-specific & foot shock, predator odor & Sprague-Dawley rat & $\begin{array}{l}0^{7}: \downarrow \mathrm{DG} \\
\text { : } 0 \mathrm{DG}\end{array}$ & {$[171,176]$} \\
\hline Species-specific & restraint & C57BL/6J mouse, Sprague-Dawley rat & $\begin{array}{c}\text { mouse: } \uparrow \mathrm{DG} \\
\text { rat: } \downarrow \text { DG }\end{array}$ & [180] \\
\hline Age-specific & footshock + restraint & C57BL/6N & $\begin{array}{l}\text { adult: } 0 \text { DG } \\
\text { aged: } \downarrow \text { DG }\end{array}$ & [181] \\
\hline \multicolumn{5}{|c|}{ SUBCHRONIC (<14 days) } \\
\hline Laboratory stressors & 7-day daily restraint & Sprague-Dawley rat & $\downarrow \mathrm{DG}$ & [182] \\
\hline $\begin{array}{l}\text { Ethologically-relevant } \\
\text { stressors }\end{array}$ & $5-, 7-$, or 10 -day daily social defeat & CFW mouse, C57BL mouse, Wistar rat & $\downarrow$ DG & [183-185] \\
\hline Brain region-specific & social defeat & C57BL mouse & $\begin{array}{l}0 \text { AMY } \\
\downarrow \text { DG }\end{array}$ & [184] \\
\hline
\end{tabular}


Table 3. Cont.

\begin{tabular}{|c|c|c|c|c|}
\hline & Stressor & Species & Impact & References \\
\hline \multicolumn{5}{|c|}{ CHRONIC ( $\geq 14$ days) } \\
\hline Laboratory stressors & $\begin{array}{c}\text { 14-day intermittent restraint } \\
\text { stress; } 20 \text {-day intermittent mild } \\
\text { stress; } 21 \text {-day daily foot shock; } 14-\text {, } \\
\text { 21-, } 42-, 49-\text {-, or } 56 \text {-day of } \\
\text { unpredictable stress; } 21 \text { - or } 42 \text {-day } \\
\text { daily restraint stress }\end{array}$ & $\begin{array}{c}\text { BALB/c mouse, Sprague-Dawley rat, } \\
\text { Wistar rat }\end{array}$ & $\downarrow D G$ & {$[122,170,178,186-190]$} \\
\hline $\begin{array}{l}\text { Ethological-relevant } \\
\text { stressors }\end{array}$ & $\begin{array}{l}\text { 35-day dominance hierarchy; } \\
\text { 14-day social defeat; } 18 \text { - or } 35 \text {-day } \\
\text { of daily social defeat; } 42 \text {-day } \\
\text { social isolation }\end{array}$ & $\begin{array}{l}\text { CD-1 mouse, C57BL/6J mouse, PV, } \\
\text { tree shrew (Tupaia belangeri), Wistar rat }\end{array}$ & $\downarrow D G$ & [191-196] \\
\hline Brain region-specific & $\begin{array}{l}\text { 21-day unpredictable stress, } \\
\text { 42-day social isolation, } 49 \text {-day } \\
\text { chronic mild stress }\end{array}$ & BALB/c, PV, Sprague-Dawley rat & $\begin{array}{c}\downarrow \text { DG, MPOA } \\
0 \text { AMY, hilus, SVZ, } \\
\text { VMH }\end{array}$ & {$[82,165,195]$} \\
\hline
\end{tabular}

Abbreviations used: AMY, amygdala; DG, dentate gyrus; MPOA, medial preoptic area; PV, prairie vole: SVZ, subventricular zone; VMH, ventromedial hypothalamus; $\uparrow:$ increase; $\downarrow$ : decrease; 0: no change; $\leftrightarrow$ : mixed findings; -: no data; ơ: male; ơ: female.

Such gonadal inhibition of DG cell proliferation might be time-specific. Restraint stress reduced DG cell proliferation at $6 \mathrm{~h}$, but not at time points immediately, $2 \mathrm{~h}$, or $3 \mathrm{~h}$ after conclusion of the exposure $[168,178,186]$. Interestingly, the timeline for inescapable shock differed substantially-with a reduction of DG cell proliferation 7 days, but not $1 \mathrm{~h}, 1$ day, or 2 days after conclusion of the exposure [173,197]. Furthermore, the gonadal inhibition appears transient-as cell proliferation returns to baseline levels (1 day following restraint and 14 days following inescapable shock) [168,173]. Evidence also supports the notion that the stressor-induced impact on DG cell proliferation might also be regulated in a sex-specific (with males potentially showing higher sensitivity in rats $[171,176]$ but see [181]), species-specific [180], and age-dependent manner [181] (see Table 3 for more detail).

It is noteworthy that the impact of stress might be related to the intensity and/or length of the stressor. Even though the exposure to a 20-min stressor (e.g., foot-shock, predator odor, social defeat) results in a robust increase in corticosterone levels, this length of stressor does not alter DG cell proliferation in male Wistar or Sprague-Dawley rats [198-200]. Similarly, one acute 40-min social defeat exposure (comprised of $5 \mathrm{~min}$ of instigation, $5 \mathrm{~min}$ of defeat, and $30 \mathrm{~min}$ of threat) as well as three 40 -min social defeat exposures do not alter DG cell proliferation in male CFW mice [183]. Using a short acute stressor (5-min of forced swimming) revealed differential impacts on DG cell proliferation dependent on the type of coping style ('reactive' versus 'proactive'). Specifically, male wild house mice with a long attack latency (reactive coping style) showed a reduction in DG cell proliferation in comparison to male wild mice with a short attack latency (proactive coping style) [179]. Indeed, previous research has shown that predictability and controllability can lessen the negative consequences of stress on the brain [201-203] and might protect against stress-induced inhibition of adult neurogenesis [171,174].

Subchronic laboratory-specific as well as ethologically-relevant stressors resulted in a reduction of DG cell proliferation in various species [182-185] (see Table 3 for details). This stress-induced reduction in DG cell proliferation is long-lasting - as 21 days following social defeat DG cell proliferation was still reduced [185]. Interestingly, subchronic psychosocial stress did not alter AMY cell proliferation in mice-possibly suggesting a brain region-specific difference [184]. Alternatively, methodological differences might explain the contradictory findings, as the length of direct exposure to the dominant animal might create a more or less intense social defeat encounter.

Chronic stress exposure (regardless of type of stressor or length) leads consistently to a reduction in DG cell proliferation in various species [165,170,178,186-190]. Interestingly, 21-day exposure to daily chronic mild stress did not alter DG cell proliferation in male Sprague-Dawley rats [82,89]. It is possible to speculate that such contradictory results can be explained by methodological differences-namely rats were exposed to behavioral tests prior to cell proliferation assessment. In addition, DG cell proliferation was lowered in response to varying lengths and a variety of ethologically-relevant stressors in several mammalian species [191-196]. 
The impact of chronic stress might be time-dependent. Specifically, 21 days of daily foot-shock experience reduced cell proliferation 2 h, but not 24 h, after the last foot-shock [198]. Furthermore, the impact of chronic stressors might also be region-specific $[82,165,195]$. Interestingly, social defeat stress and subsequent isolation housing in long-tailed hamsters reduced cell proliferation in the AMY and VMH, without altering DG cell proliferation [204]. At this point, it is not clear whether the lack of an effect in the hippocampus reflects a species or a methodological difference.

\subsection{Hormonal Inhibition of Cell Survival}

Although it has not been studied in detail yet, there is evidence that acute stress exposure negatively impacts cell survival (see Table 4). To our knowledge, only one study to date assessed the impact of an acute laboratory-specific stressor on cell survival and observed a reduction in DG cell survival [174]. Similarly, studies that investigated the impact of ethologically-relevant stressors observed the reduction in DG cell survival [164,200]. It is noteworthy that stress exposure did not impact immediate survival (2-day old adult-generated cells), but had negative impacts on both short-term (7-day old adult-generated cells) and long-term (28-day old adult-generated cells) survival in male Sprague-Dawley rats [200]. The stressor intensity might play a role in the longevity of the stressor-induced reduction of DG cell survival, as predator odor exposure reduced short-term (7-day), but not long-term (21-day) survival in male Sprague-Dawley rats [164].

Table 4. The effects of stressors on cell survival in several mammalian species.

\begin{tabular}{|c|c|c|c|c|}
\hline & Stressor & Species & Impact & References \\
\hline \multicolumn{5}{|c|}{ ACUTE (same day) } \\
\hline Laboratory stressor & tail shock & Sprague-Dawley rat & $\downarrow \mathrm{DG}$ & {$[174]$} \\
\hline $\begin{array}{c}\text { Ethologically-relevant } \\
\text { stressors }\end{array}$ & predator odor, social defeat & Sprague-Dawley rat & $\downarrow \mathrm{DG}$ & {$[164,200]$} \\
\hline \multicolumn{5}{|c|}{ SUBCHRONIC and CHRONIC } \\
\hline Laboratory stressors & $\begin{array}{l}\text { 21-day daily restraint, } \\
\text { 21-day chronic mild stress, } \\
\text { 49-day chronic mild stress }\end{array}$ & $\begin{array}{l}\text { BALB/c, CD } 1 \text { mouse, } \\
\text { Sprague-Dawley rat }\end{array}$ & $\downarrow D G$ & {$[80,82,158,165,178]$} \\
\hline $\begin{array}{c}\text { Ethologically-relevant } \\
\text { stressors }\end{array}$ & $\begin{array}{l}10-, 18-, \text { or } 35-\text { day daily } \\
\text { social defeat, } 42-\text { day } \\
\text { social isolation }\end{array}$ & $\begin{array}{c}\text { C57BL/6, PV, } \\
\text { Sprague-Dawley rat, } \\
\text { Wistar rat }\end{array}$ & $\downarrow D G$ & {$[87,192,195,205]$} \\
\hline Brain region-specific & chronic mild stress, restraint & $\begin{array}{c}\text { CD-1 mouse, PV, } \\
\text { Sprague-Dawley rat }\end{array}$ & $\begin{array}{c}\downarrow \text { AMY, DG, VMH } \\
\text { 0 CA } 1, \text { CA } 3, \text { hilus, MPOA }\end{array}$ & {$[80,82,195]$} \\
\hline
\end{tabular}

Abbreviations used: AMY, amygdala; CA 1, CA region 1 in the hippocampus; CA 3, CA region 3 in the hippocampus; DG, dentate gyrus; MPOA, medial preoptic area; VMH, ventromedial hypothalamus: $\uparrow$ : increase; $\downarrow$ : decrease; 0 : no change; $\leftrightarrow$ : mixed findings; -: no data.

Subchronic and chronic stress exposure leads consistently to a reduction in DG cell survival in various species [80,82,158,165,178,191,192,195,205]—regardless of laboratory-specific or ethologically-relevant stressor (see Table 4). The majority of adult-generated DG cells display a neuronal phenotype $[80,83,165,178,192,206]$-suggesting that exposure to a chronic stressor reduces adult neurogenesis. Research has shown that the stress-induced reduction of cell survival might be brain region-specific $[80,82,195]$.

It has also been shown that the type of stressor might impact cell survival in a sex-specific manner. Chronic social isolation resulted in lower levels of DG cell survival in intact female prairie voles (42 days of social isolation [195]) but did not alter DG cell survival in male Sprague-Dawley (12 or 34 days of social isolation $[83,206])$. Indeed, sex differences in the influence of stress on neural plasticity has previously been noted. For example, in response to chronic restraint stress males display atrophy of apical CA3 dendrites, whereas females display atrophy in basal CA3 dendrites [207]. Stress exposure also alters HPA axis functioning in a sex-specific manner $[187,208]$. However, at the moment it cannot be ruled out that species differences (prairie vole versus rat) or length of social isolation underlie these differences. 
Interestingly, if BrdU is used to label cells prior to a subchronic (e.g., social defeat) or chronic stressor (e.g., chronic daily foot-shock exposure, chronic twice daily unpredictable stress, or daily chronic restraint stress), the rate of survival of adult-generated DG cells is not altered in male Wistar rats $[170,178,185,198]$.

\subsection{Hormonal Impact on Neuronal Differentiation}

Stress exposure has resulted in mixed findings for its impact on neuronal differentiation. Exposure to acute stressors (such as 20-min psychosocial stress or 30 trials of uncontrollable foot-shock) as well as exposure to various chronic stressors (including 21 days of chronic restraint stress; 21 days of chronic unpredictable stress; 10 or 32 days of social isolation; and 10,18, or 35 days of daily chronic social defeat) did not alter neuronal differentiation in male C57BL/6 mice, Sprague-Dawley rats, or Wistar rats $[83,170,172,178,191,192,200,205,206]$. Interestingly, other studies have found that stressors decrease neuronal differentiation. Namely, exposure to an acute stressor (30-min foot shock and 30-min restraint)—a procedure that causes long-lasting and robust increase in serum corticosterone-decreased the percentage of adult-generated DG neurons (assessed by BrdU/Dcx double-labeling) in male Balb/C mice $[168,169]$. Furthermore, the exposure to 80 sets of tail shock reduced DG adult neurogenesis (assessed by BrdU/NeuN double-labeling) in male Sprague-Dawley rats [174]. Similarly, exposure to a chronic stressor (21 days of daily restraint stress or daily foot-shock exposure) reduced DG neuronal differentiation (assessed by BrdU/Dcx or BrdU/NeuN double-labeling) in male CD1 mice and male Wistar rats [80,198]. Furthermore, 42 days of social isolation reduced the rate of neuronal differentiation (assessed by BrdU/NeuN double-labeling) in the DG and AMY of female prairie voles [195]. At this time, it is not clear whether these contradictory findings might possibly suggest a sex difference, strain difference, difference in stressor, or differences in methodology (e.g., BrdU/NeuN double-label vs. Dcx-labeling).

In sum, the stress-induced release of glucocorticoids is one of the most profound environmental suppressors of adult neurogenesis. Indeed, laboratory-specific as well as ethologically-relevant stressors inhibit multiple neurogenic stages in various mammalian species (including mouse, rat, tree shrew, marmoset, and macaque). Furthermore, acute, subchronic, as well as chronic stress exposure results in a potent suppressive effect on adult neurogenesis—suggesting that the stress duration may have lesser role in affecting adult neurogenesis.

\section{Hormonal Neuroprotective Effects}

In addition to facilitating adult neurogenesis, hormones might also have a neuroprotective effect on adult-generated neurons. Here, we will discuss the hormonal neuroprotection by recruiting other neurochemicals as well as the evidence of hormones ameliorating the stress-induced reduction of adult neurogenesis.

\subsection{Hormonal Neuroprotection via Recruitment of Other Neurochemicals}

Adult neurogenesis-just one aspect of the highly complex process of neuroplasticity-is not solely regulated by hormones [47]. Indeed, gonadal hormones might have neuroprotective properties in part by interacting with neurotrophic factors as well as neuromodulators [209]. Here, we will discuss the interaction of estrogen and brain derived neurotrophic factor (BDNF)—a neurotrophin that regulates adult neurogenesis. Furthermore, we will review the interaction between estrogen and serotonin (5-HT) and oxytocin (OT), as 5-HT and OT have been shown to play a role in adult neurogenesis. While very little research has been conducted on the interaction between other gonadal hormones (such as testosterone) and BDNF, 5-HT, or OT, we have included these studies into our discussion.

\subsubsection{Hormonal Neuroprotection via Recruitment of the Neurotrophin BDNF}

BDNF, which is widely expressed throughout the mammalian brain [210], plays an important role in the development [211,212], survival [213], maintenance [212], and plasticity [214] of neurons. 
In particular, BDNF has been implicated in various aspects of neuronal plasticity including long-term potentiation and neuronal excitability [215], synaptogenesis and spine formation [216], and dendritic growth [217-221], as well as adult neurogenesis [222,223]. Chronic BDNF infusion or BDNF viral overexpression in the lateral ventricles upregulate the survival of adult-generated cells-leading to more new neurons in the MOB, striatum, HYP, and thalamus [224,225]. Similarly, chronic BDNF infusion into the hippocampus increases of survival of adult-generated neurons [226]. Furthermore, BDNF-expressing cells have been reported in various neurogenic brain regions including the amygdala, hippocampus, and HYP [227-230].

BDNF interacts with estrogen [231-233]. Specifically, researchers found that estrogen receptors colocalize to neurons expressing BDNF and its receptor trkB in the basal forebrain [234]. Such colocalization was also observed in the cerebral cortex, HYP, and hippocampus [235]. Furthermore, researchers found an estrogen-sensitive response element on the BDNF gene [236] — which allows estrogen to have a direct genomic impact on BDNF expression. Consistent with this notion, it has been found that BDNF mRNA levels and BDNF immunoreactivity in the hippocampus vary throughout the estrous cycle in the rat [237-239]. While estrogen administration increases the expression of BDNF and its receptor in the cortex, MOB, and hippocampus [236,240,241]; OVX leads to a noticeable reduction of BDNF mRNA levels in the hippocampus, AMY, cerebral cortex, and MOB [236,240-243]. Interestingly, this OVX-induced reduction in BDNF mRNA levels can be reversed by estrogen replacement following OVX $[236,237,240-244]$. Estrogen-treated animals also show more retrograde transport of BDNF in forebrain circuits-a mechanism by which BDNF exerts its neuroprotective role [245]. While the specific underlying mechanism is not fully understood, these results taken together convincingly suggest an interaction between estrogen and BDNF. It can further be speculated that this interaction might be involved in mediating adult neurogenesis.

\subsubsection{Hormonal Neuroprotection via Recruitment of 5-HT}

5-HT regulates diverse brain functions such as autonomic nervous system reactivity, sleep cycles, and appetite [246,247]. Furthermore, 5-HT has a role in regulating various emotional behaviors such as anxiety, aggression, and affiliative behaviors [248]. Serotonergic projections originating from the brain stem raphe nuclei innervate nearly every part of the forebrain including the HYP, AMY, prefrontal cortex, and hippocampus where the 5-HT effects are mediated via 15 different 5-HT receptors [249].

5-HT seems to play a role in the regulation of adult neurogenesis [250-252]. Specifically, the depletion of serotonin (by ablating 5-HT neurons using a 5-HT neurotoxin) reduced DG cell proliferation in male and female Wistar rats, but not male Lister hooded rats [114,253-255]. Lesion-induced reduction in cell proliferation in rats was reversed by using fetal 5-HT grafts [254]. Acute fluoxetine (a 5-HT agonist by selectively inhibiting 5-HT reuptake) treatment did not alter DG cell proliferation in male Sprague-Dawley rats [256]. Interestingly, the direct manipulation of 5-HT receptor activity via receptor agonists or antagonists resulted in oppositional effects on mediating DG cell proliferation. The acute activation of the $5-\mathrm{HT}_{1 \mathrm{~A}}$ receptor increased $\mathrm{DG}$ and $\mathrm{SVZ}$ cell proliferation in male Wistar rats and female C57Bl/6 mice $[257,258]$, whereas the acute blockade resulted in a reduction of DG cell proliferation in male Sprague-Dawley rats [259]. Interestingly, the acute blockade of 5- $\mathrm{HT}_{2}$ receptors mirrored the effects of $5-\mathrm{HT}_{1 \mathrm{~A}}$ receptor activation [258]. While acutely activating the $5-\mathrm{HT}_{1 \mathrm{~B}}$ receptor did not alter DG cell proliferation in male Wistar rats [257], it reduced SVZ cell proliferation in female C57B1/6 mice [258] — suggesting a potential brain region- or species-specific effect. Further support for a species-specific effect of the regulation of 5-HT receptor activity comes from the finding that a $5-\mathrm{HT}_{2 \mathrm{C}}$ agonist did not alter DG cell proliferation in male Wistar rats [257] but reduced DG cell proliferation in female C57Bl/6 mice [258]. To our knowledge, there is only one study to date that assessed the impact of acute 5-HT system manipulation on cell survival. The researchers noted that an acute treatment with a partial 5- $\mathrm{HT}_{1 \mathrm{~A}}$ agonist increased the survival of adult-generated $\mathrm{MOB}$ and DG neurons in opossums [6]. Similarly, there is only one study we are aware of that investigated the 
impact on neuronal differentiation. The researchers found that the activation of $5-\mathrm{HT}_{1 \mathrm{~A}} \mathrm{R}$ increased the number of Dcx-labeled cells in the hippocampus [258].

Subchronic ( 5 days) depletion of serotonin (by inhibiting 5-HT synthesis) reduced cell proliferation in the DG and SVZ of male Wistar rats [260]. Subchronic (7 days) activation of 5-HT $\mathrm{HT}_{1 \mathrm{~A}}$ receptor had no effect on DG cell proliferation, whereas treatment of a $5-\mathrm{HT}_{1 \mathrm{~A}}$ receptor antagonist reduced the number of BrdU-labeled cells in the DG [258]. Furthermore, subchronic treatment with 5- $\mathrm{HT}_{1 \mathrm{~A}} \mathrm{R}$ agonist did not alter the number of Dcx-labeled cells in the DG of female C57Bl/6 mice [258].

Chronic treatment $(11,14,21,28,42$, or 63 days) with fluoxetine increased DG adult neurogenesis in male Sprague-Dawley rats, Brown-Norway rats, Lister hooded rats, Wistar rats, 129/SV, and C57BL/6 mice $[110,256,261-265]$. It should be noted that 25 days of fluoxetine treatment in male aged Sprague-Dawley rats (12 months old) and male aged C57BL/6 mice (6 or 12 month old) did not alter DG cell proliferation [266,267]. Interestingly, researchers observed that chronic fluoxetine treatment for 42 and 63, but not 21, days reduced SVZ cell proliferation in male C57BL/6J mice [268] - suggesting that 5-HT might mediate adult neurogenesis differently across brain regions (SVZ versus DG) and potentially differently across species (rat versus mouse) [269]. The administration of a 5-HT $1 \mathrm{~A}$ agonist delivered via an osmotic pump, but not daily injections, for 14 days increased DG cell proliferation in male Lister hooded rats $[255,264]$.

Chronic treatment (28 days) with fluoxetine increased DG cell survival in adult ( 3 month old), but not aged ( 6 or 12 month old) male C57BL/6 mice [267]. The majority of these adult-generated cells expressed a neuronal phenotype-suggesting that chronic fluoxetine treatment increased DG adult neurogenesis. Similarly, chronic treatment (28 days) with fluoxetine increased the number of immature DG neurons in male adult, but not aged, Wistar rats [263,266]; and chronic treatment (14 days) with a partial $5-\mathrm{HT}_{1 \mathrm{~A}}$ agonist increased the number of immature neurons in the hippocampus of male Sprague-Dawley rats [270]. Further, a 14-day treatment with 5- $\mathrm{HT}_{1 \mathrm{~A}}$ agonist delivered via an osmotic pump, but not via daily injections, increased hippocampal cell survival and showed a higher number of neuronal hippocampal cells than saline-treated animals in male Lister hooded rats [255,264].

Various studies suggest that ovarian steroids, such as estrogen, interact with the 5-HT system [104]. One example of such an interaction is the localization of estrogen receptors to 5-HT neurons in various species including guinea pigs, macaques, mice, and rats [271-275]. Furthermore, there is evidence that estrogen affects the function of the 5-HT system [276]. Acute estrogen treatment (32-h duration) increased levels of 5- $\mathrm{HT}_{2 \mathrm{~A}}$ mRNA in the dorsal raphe of male castrated rats [277]. Chronic estrogen treatment also decreased the expression of $5 \mathrm{HT}_{2 \mathrm{c}}$ receptors mRNA in the HYP of spayed female pigtail macaque (Macaca nemestrina) without altering the expression of $5-\mathrm{HT}_{1 \mathrm{~A}}$ or 5- $\mathrm{HT}_{2 \mathrm{~A}}$ mRNA [278]. Interestingly, chronic estrogen treatment in female OVX rats reduced $5 \mathrm{HT}_{1 \mathrm{~A}}$ mRNA in the hippocampus [279]. These contradictory results between these two studies [278,279] might suggest a possible brain-region specific effect or a species difference. Another example of the interaction of estrogen and 5-HT involved the main process to terminate 5-HT neurotransmission, the 5-HT reuptake transporter (SERT). Estrogen treatment in the female rhesus monkey raphe nuclei reduced the expression of 5-HT transporter (SERT) mRNA [280]—suggesting that estrogen can alter 5-HT neurotransmission.

A potential underlying mechanism for the enhancing effect of $5 \mathrm{HT}$ on adult neurogenesis is the role of 5-HT in the regulation of BDNF mRNA. For example, using a selective 5-HT reuptake inhibitor causes an increase of BDNF mRNA in the hippocampus [281]. Furthermore, the stress-induced reduction of BDNF mRNA in the hippocampus was prevented by the pretreatment with a 5-HT antagonist [282].

While more research needs to directly assess the estrogen stimulation of hippocampal cell proliferation via 5-HT, researchers found that the administration of a precursor to 5-HT can reverse the reduction in hippocampal cell proliferation following OVX, whereas estrogen treatment was unable to reverse the OVX-induced reduction in cell proliferation in rats treated with a 5-HT antagonist [114]. 


\subsubsection{Hormonal Neuroprotection via Recruitment of OT}

OT is released during sexual activity and it plays an essential role in facilitating sexual and affiliative behavior, including the development of a pair bond [283-285]. Furthermore, OT contributes significantly to the initiation of maternal behavior, regulates the selective bond between mother and offspring, and might play an important role in paternal behavior [286-288]. OT is primarily produced in the HYP, which projects to the pituitary gland as well as to various regions within the brain [283]. Some evidence has accumulated that OT might be a factor influencing adult neurogenesis.

Indeed, an acute peripheral or central (into the hippocampus) OT administration upregulated DG cell proliferation in male rats without altering cell proliferation in the SVZ [289]. This effect was dose-dependent as $1 \mathrm{mg} / \mathrm{kg}$ dose led to an increase in cell proliferation, whereas $10 \mathrm{mg} / \mathrm{kg}$ caused no change. Subchronic OT treatment increased DG adult neurogenesis [289]. An acute OT administration did not alter the survival of adult-generated DG cells as assessed 1 or 3 weeks following OT administration [289].

Subchronic peripheral OT administration increased the survival of adult-generated DG cells in male rats [289]. The majority of these cells expressed a neuronal phenotype. Subchronic peripheral OT administration did not alter neuronal differentiation in the DG of male rats [289].

Various studies suggest that ovarian steroids, such as estrogen, interact with the OT system. Specifically, researchers found that estrogen receptors (specifically ER beta) colocalize to OT-producing neurons in the HYP $[290,291]$. Natural fluctuations of the gonadal hormones influence the OT system. Specifically, prior to parturition, which, leads to an increase in estrogen [134], OTR expression is increased [292]. Additionally, estrogen and testosterone treatment increase OTR binding and OT mRNA levels in the brain, whereas these levels are reduced following castration [293-295]. Future studies should investigate the underlying mechanism for this OT mediation of adult neurogenesis by investigating whether OT receptors are expressed by proliferating precursor cells as well as what mechanism estrogen has.

\subsection{Hormonal Amelioration of Stressor-Induced Reduction of Adult Neurogenesis}

Exposure to stressors and the associated upregulation of glucocorticoids have been shown to downregulate neurogenesis. There is evidence to suggest that gonadal hormones might mediate the impact of the stress response on adult neurogenesis.

Stress exposure or corticosterone administration inhibit adult neurogenesis and alter the functioning of the BDNF, 5-HT, and OT systems [296-298]-chemicals involved in the neuroprotection of adult-generated neurons. Interestingly, gonadal steroids can confer resiliency to the stress-induced reduction of adult neurogenesis. For example, TX and chronic mild stress in male rats reduced DG cell proliferation and survival more than chronic mild stress alone [82]. Similarly, TX and isolation stress in male rats resulted in a lower survival rate of adult-generated DG neurons than isolation alone [83]. It should be noted that the majority of these adult-generated cells expressed a neuronal phenotype. Furthermore, environmental manipulation of gonadal steroids (i.e., mating exposure, which, in turn, alters the testosterone system) can buffer against the negative impact of stress in male rats [80]. Specifically, males exposed to both daily restraint stress and mating had more BrdU-labeled DG cells (indicating a higher level of cell survival) than rats which were only restraint. The majority of these cells expressed a neuronal phenotype, but the number of BrdU/NeuN double-labeled cells did not differ across groups-suggesting that mating activity buffers against stress-induced reduction of hippocampal adult neurogenesis.

Pharmacological manipulations of gonadal steroids can also buffer against the negative impact of stressors on adult neurogenesis. Estrogen treatment prevented the chronic stress-induced dendritic retraction in the hippocampal of female OVX Sprague-Dawley rats [299]. Estrogen treatment also attenuated hippocampal neuronal loss in chronically stressed female OVX rats (Takuma 2007) [300]. Testosterone treatment in male Sprague-Dawley rats prevented the reduction in hippocampal cell proliferation following social defeat stress [185]. 


\section{Conclusions}

The evidence we reviewed here strongly indicate that hormones have a multifaceted impact in regulating adult neurogenesis (Figure 2). We highlight that gonadal hormones seem to facilitate while glucocorticoids seem to inhibit adult neurogenesis. Furthermore, gonadal steroids have been shown to have a neuroprotective effect on adult-generated cells by interacting with BDNF, 5-HT, and OT. These findings are not surprising as the hippocampus and other neurogenic regions (such as the AMY and MOB) are enriched with receptors for gonadal hormones, prolactin, glucocorticoids, BDNF, 5-HT, and OT. However, the exact mechanisms-whether acting on astrocytes or directly on progenitor cells-for hormones to impact adult neurogenesis in such a diverse pattern still remain to be elucidated. Future studies should systematically investigate the functional implications of this multifaceted regulation of hormones on motivated behaviors. Such investigations might further elucidate the observed differences across species, brain-regions, and age of subjects.

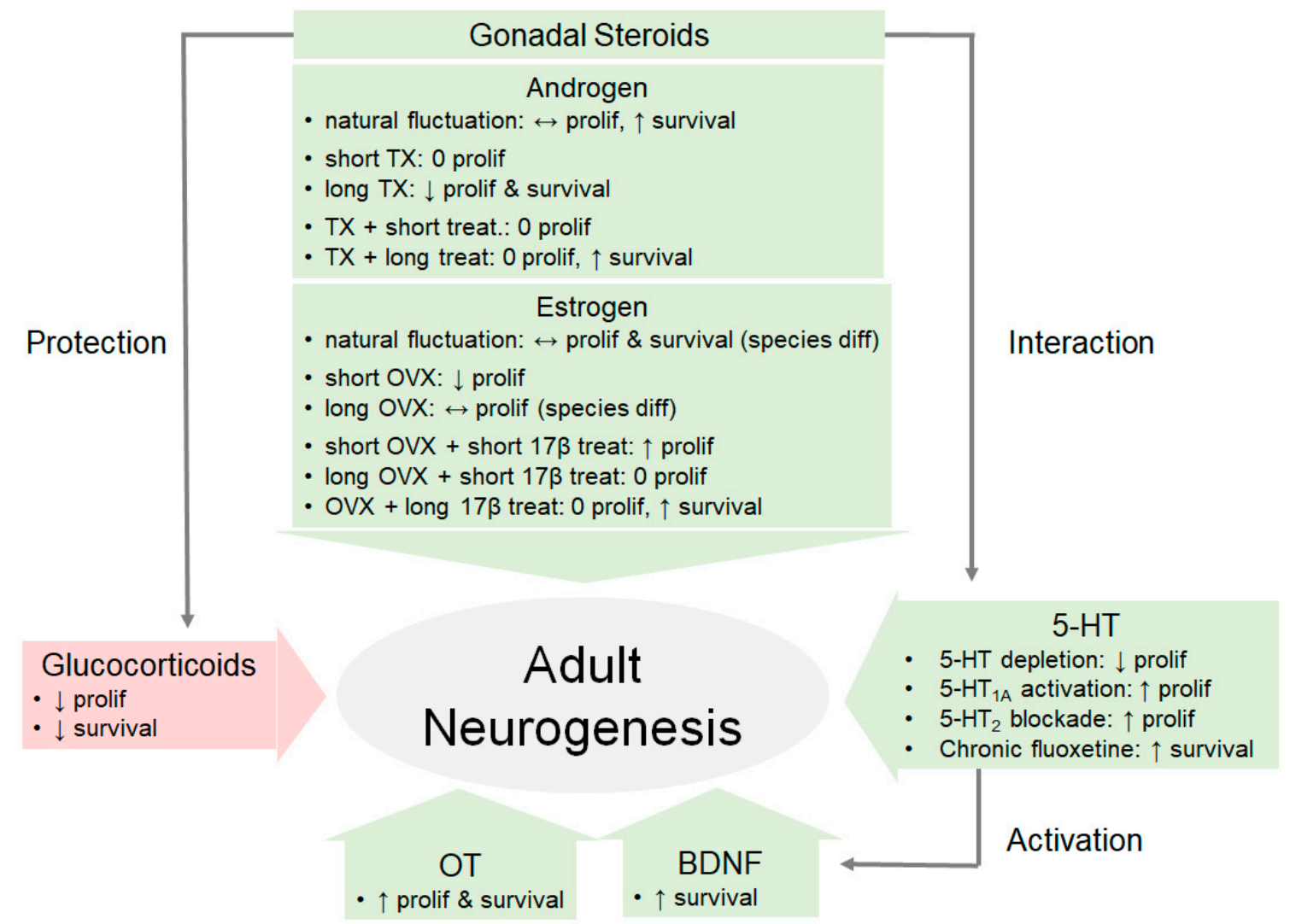

Figure 2. Hormones have a multifaceted impact on adult neurogenesis. This model diagram illustrates some of the effects of various hormones on hippocampal adult neurogenesis, including the facilitation by gonadal hormones, inhibition by glucocorticoids, and protection via the recruitment of other neurochemicals. BDNF, brain-derived neurotrophic factor; diff, difference; long, long-term; OVX, ovariectomy; OT, oxytocin; prolif, proliferation; $17 \beta, 17 \beta$ estradiol; short, short-term; treat, treatment; TX, castration; $\uparrow$ : increase; $\downarrow$ : decrease; $\leftrightarrow$ : mixed findings; 0 : no change.

Funding: This work was partially funded by grants from the National Institutes of Health [NIMH R01-108527, NIMH R01-109450, and NIMH R21-111998] to Z.W.

Acknowledgments: We thank the anonymous reviewers for their constructive and helpful suggestions.

Conflicts of Interest: The authors declare no conflict of interest. 


\section{Abbreviations}

$\begin{array}{ll}\text { AMY } & \text { amygdala } \\ \text { AOB } & \begin{array}{l}\text { accessory olfactory bulb } \\ \text { BDNF }\end{array} \\ \text { brain-derived neurotrophic factor } \\ \text { BrdU } & \text { 5-bromo-3'-deoxyuridine } \\ \text { Dcx } & \begin{array}{l}\text { doublecortin } \\ \text { dentate gyrus }\end{array} \\ \text { DG } & \text { dihydrotestosterone } \\ \text { DHT } & \text { granular cell layer in the dentate gyrus } \\ \text { GCL } & \text { glomerular cell layer } \\ \text { GlCL } & \text { granular cell layer } \\ \text { GrCL } & \text { hypothalamus } \\ \text { HYP } & \text { molecular cell layer } \\ \text { MCL } & \text { posterior medial AMY } \\ \text { MeP } & \text { main olfactory bulb } \\ \text { MOB } & \text { medial preoptic area } \\ \text { MPOA } & \text { serotonin } \\ \text { 5-HT } & \text { oxytocin } \\ \text { OT } & \text { rostral migratory stream } \\ \text { rms } & \text { subgranular zone in the dentate gyrus } \\ \text { SGZ } & \text { subventricular zone of the lateral ventricles }\end{array}$

\section{References}

1. Gould, E.; Gross, C.G. Neurogenesis in adult mammals: Some progress and problems. J. Neurosci. 2002, 22, 619-623. [CrossRef]

2. Gross, C.G. Neurogenesis in the adult brain: Death of a dogma. Nat. Rev. Neurosci. 2000, 1, 67-73. [CrossRef] [PubMed]

3. Gould, E.; Reeves, A.J.; Fallah, M.; Tanapat, P.; Gross, C.G.; Fuchs, E. Hippocampal neurogenesis in adult Old World primates. Proc. Natl. Acad. Sci. USA 1999, 96, 5263-5267. [CrossRef] [PubMed]

4. Gould, E.; Tanapat, P.; McEwen, B.S.; Flugge, G.; Fuchs, E. Proliferation of granule cell precursors in the dentate gyrus of adult monkeys is diminished by stress. Proc. Natl. Acad. Sci. USA 1998, 95, 3168-3171. [CrossRef]

5. Kornack, D.R.; Rakic, P. Continuation of neurogenesis in the hippocampus of the adult macaque monkey. Proc. Natl. Acad. Sci. USA 1999, 96, 5768-5773. [CrossRef] [PubMed]

6. Grabiec, M.; Turlejski, K.; Djavadian, R.L. The partial 5-HT1A receptor agonist buspirone enhances neurogenesis in the opossum (Monodelphis domestica). Eur. Neuropsychopharmacol. 2009, 19, 431-439. [CrossRef] [PubMed]

7. Eriksson, P.S.; Perfilieva, E.; Bjork-Eriksson, T.; Alborn, A.M.; Nordborg, C.; Peterson, D.A.; Gage, F.H. Neurogenesis in the adult human hippocampus. Nat. Med. 1998, 4, 1313-1317. [CrossRef] [PubMed]

8. Kempermann, G.; Gage, F.H.; Aigner, L.; Song, H.; Curtis, M.A.; Thuret, S.; Kuhn, H.G.; Jessberger, S.; Frankland, P.W.; Cameron, H.A. Human adult neurogenesis: Evidence and remaining questions. Cell Stem Cell 2018, 23, 25-30. [CrossRef]

9. Balu, D.T.; Lucki, I. Adult hippocampal neurogenesis: Regulation, functional implications, and contribution to disease pathology. Neurosci. Biobehav. Red. 2009, 33, 232-252. [CrossRef]

10. Jorgensen, C. Adult mammalian neurogenesis and motivated behaviors. Integr. Zool 2018, 13, 655-672. [CrossRef]

11. Amrein, I.; Dechmann, D.K.N.; Winter, Y.; Lipp, H.-P. Absent or low rate of adult neurogenesis in the hippocampus of bats (Chiroptera). PLoS ONE 2007, 2, e455. [CrossRef] [PubMed]

12. Zhao, C.; Teng, E.M.; Summers, R.G., Jr.; Ming, G.L.; Gage, F.H. Distinct morphological stages of dentate granule neuron maturation in the adult mouse hippocampus. J. Neurosci. 2006, 26, 3-11. [CrossRef] [PubMed]

13. Zhao, C.; Deng, W.; Gage, F.H. Mechanisms and functional implications of adult neurogenesis. Cell 2008, 132, 645-660. [CrossRef] [PubMed] 
14. Lois, C.; Alvarez-Buylla, A. Long-distance neuronal migration in the adult mammalian brain. Science 1994, 264, 1145-1148. [CrossRef]

15. Antzoulatos, E.; Magorien, J.E.; Wood, R.I. Cell proliferation and survival in the mating circuit of adult male hamsters: Effects of testosterone and sexual behavior. Horm. Behav. 2008, 54, 735-740. [CrossRef]

16. Bernier, P.J.; Bedard, A.; Vinet, J.; Levesque, M.; Parent, A. Newly generated neurons in the amygdala and adjoining cortex of adult primates. Proc. Natl. Acad. Sci. USA 2002, 99, 11464-11469. [CrossRef]

17. Fowler, C.D.; Liu, Y.; Ouimet, C.; Wang, Z. The effects of social environment on adult neurogenesis in the female prairie vole. J. Neurobiol. 2002, 51, 115-128. [CrossRef]

18. Akbari, E.M.; Chatterjee, D.; Levy, F.; Fleming, A.S. Experience-dependent cell survival in the maternal rat brain. Behav. Neurosci. 2007, 121, 1001-1011. [CrossRef]

19. Lieberwirth, C.; Wang, Z. The social environment and neurogenesis in the adult mammalian brain. Front. Hum. Neurosci. 2012, 6, 1-19. [CrossRef]

20. Huang, L.; DeVries, G.J.; Bittman, E.L. Photoperiod regulates neuronal bromodeoxyuridine labeling in the brain of a seasonally breeding mammal. J. Neurobiol. 1998, 36, 410-420. [CrossRef]

21. Kokoeva, M.V.; Yin, H.; Flier, J.S. Neurogenesis in the hypothalamus of adult mice: Potential role in energy balance. Science 2005, 310, 679-683. [CrossRef] [PubMed]

22. Dayer, A.G.; Cleaver, K.M.; Abouantoun, T.; Cameron, H.A. New GABAergic interneurons in the adult neocortex and striatum are generated from different precursors. J. Cell Biol. 2005, 168, 415-427. [CrossRef] [PubMed]

23. Gould, E.; Reeves, A.J.; Graziano, M.S.; Gross, C.G. Neurogenesis in the neocortex of adult primates. Science 1999, 286, 548-552. [CrossRef] [PubMed]

24. Gould, E.; Vail, N.; Wagers, M.; Gross, C.G. Adult-generated hippocampal and neocortical neurons in macaques have a transient existence. Proc. Natl. Acad. Sci. USA 2001, 98, 10910-10917. [PubMed]

25. Bedard, A.; Cossette, M.; Levesque, M.; Parent, A. Proliferating cells can differentiate into neurons in the striatum of normal adult monkey. Neurosci. Lett. 2002, 328, 213-216. [CrossRef]

26. Kuhn, H.G.; Eisch, A.J.; Spalding, K.; Peterson, D.A. Detection and phenotypic characterization of adult neurogenesis. Cold Spring Harb. Perspect. Biol. 2016, 8, a025981. [CrossRef]

27. Kempermann, G.; Song, H.; Gage, F.H. Neurogenesis in the adult hippocampus. Cold Spring Harb. Perspect. Biol. 2015, 7, a018812. [CrossRef]

28. Cameron, H.A.; McKay, R.D. Adult neurogenesis produces a large pool of new granule cells in the dentate gyrus. J. Comp. Neurol. 2001, 435, 406-417. [CrossRef]

29. Kee, N.; Sivalingam, S.; Boonstra, R.; Wojtowicz, J.M. The utility of Ki-67 and BrdU as proliferative markers of adult neurogenesis. J. Neurosci. Meth. 2002, 115, 97-105. [CrossRef]

30. Scholzen, T.; Gerdes, J. The Ki-67 protein: From the known and the unknown. J. Cell Physiol. 2000, 182, 311-322. [CrossRef]

31. Miller, M.W.; Nowakowski, R.S. Use of bromodeoxyuridine-immunohistochemistry to examine the proliferation, migration and time of origin of cells in the central nervous system. Brain Res. 1988, 457, 44-52. [CrossRef]

32. Hendzel, M.J.; Wei, Y.; Mancini, M.A.; Van Hooser, A.; Ranalli, T.; Brinkley, B.; Bazett-Jones, D.P.; Allis, C.D. Mitosis-specific phosphorylation of histone $\mathrm{H} 3$ initiates primarily within pericentromeric heterochromatin during G2 and spreads in an ordered fashion coincident with mitotic chromosome condensation. Chromosoma 1997, 106, 348-360. [CrossRef] [PubMed]

33. Seki, T.; Arai, Y. Highly polysialylated neural cell adhesion molecule (NCAM-H) is expressed by newly generated granule cells in the dentate gyrus of the adult rat. J. Neurosci. 1993, 13, 2351-2358. [CrossRef] [PubMed]

34. Leuner, B.; Glasper, E.R.; Gould, E. Thymidine analog methods for studies of adult neurogenesis are not equally sensitive. J. Comp. Neurol. 2009, 517, 123-133. [CrossRef]

35. Eisch, A.J.; Mandyam, C.D. Adult neurogenesis: Can analysis of cell cycle proteins move us "Beyond BrdU"? Curr. Pharm. Biotechnol. 2007, 8, 147-165. [CrossRef]

36. Brown, J.P.; Couillard-Despres, S.; Cooper-Kuhn, C.M.; Winkler, J.; Aigner, L.; Kuhn, H.G. Transient expression of doublecortin during adult neurogenesis. J. Comp. Neurol. 2003, 467, 1-10. [CrossRef] 
37. Mullen, R.J.; Buck, C.R.; Smith, A.M. NeuN, a neuronal specific nuclear protein in vertebrates. Development 1992, 116, 201-211.

38. Alexander, J.E.; Hunt, D.F.; Lee, M.K.; Shabanowitz, J.; Michel, H.; Berlin, S.C.; MacDonald, T.L.; Sundberg, R.J.; Rebhun, L.I.; Frankfurter, A. Characterization of posttranslational modifications in neuron-specific class III beta-tubulin by mass spectrometry. Proc. Natl. Acad. Sci. 1991, 88, 4685-4689. [CrossRef]

39. Hastings, N.B.; Gould, E. Rapid extension of axons into the CA3 region by adult-generated granule cells. J. Comp. Neurol. 1999, 413, 146-154. [CrossRef]

40. Biebl, M.; Cooper, C.M.; Winkler, J.; Kuhn, H.G. Analysis of neurogenesis and programmed cell death reveals a self-renewing capacity in the adult rat brain. Neurosci. Lett. 2000, 291, 17-20. [CrossRef]

41. Ormerod, B.K.; Galea, L.A.M. Reproductive status influences the survival of new cells in the dentate gyrus of adult male meadow voles. Neurosci. Lett. 2003, 346, 25-28. [CrossRef]

42. Ryu, J.R.; Hong, C.J.; Kim, J.Y.; Kim, E.-K.; Sun, W.; Yu, S.-W. Control of adult neurogenesis by programmed cell death in the mammalian brain. Mol. Brain 2016, 9, 43. [CrossRef] [PubMed]

43. Winner, B.; Cooper-Kuhn, C.M.; Aigner, R.; Winkler, J.; Kuhn, H.G. Long-term survival and cell death of newly generated neurons in the adult rat olfactory bulb. Eur. J. Neurosci. 2002, 16, 1681-1689. [CrossRef] [PubMed]

44. Heine, V.M.; Maslam, S.; Joëls, M.; Lucassen, P.J. Prominent decline of newborn cell proliferation, differentiation, and apoptosis in the aging dentate gyrus, in absence of an age-related hypothalamus-pituitary-adrenal axis activation. Neurobiol. Aging 2004, 25, 361-375. [CrossRef]

45. Ming, G.L.; Song, H. Adult neurogenesis in the mammalian central nervous system. Annu. Rev. Neurosci. 2005, 28, 223-250. [CrossRef]

46. Abrous, D.N.; Koehl, M.; Le Moal, M. Adult neurogenesis: From precursors to network and physiology. Physiol. Rev. 2005, 85, 523-569. [CrossRef]

47. Vaidya, V.A.; Vadodaria, K.C.; Jha, S. Neurotransmitter regulation of adult neurogenesis: Putative therapeutic targets. CNS Neurol. Disord. Drug Targets 2007, 6, 358-374. [CrossRef]

48. Pawluski, J.L.; Brummelte, S.; Barha, C.K.; Crozier, T.M.; Galea, L.A. Effects of steroid hormones on neurogenesis in the hippocampus of the adult female rodent during the estrous cycle, pregnancy, lactation and aging. Front. Neuroendocrinol. 2009, 30, 343-357. [CrossRef]

49. Opendak, M.; Briones, B.A.; Gould, E. Social behavior, hormones and adult neurogenesis. Front. Neuroendocrinol. 2016, 41, 71-86. [CrossRef]

50. Mahmoud, R.; Wainwright, S.R.; Galea, L.A. Sex hormones and adult hippocampal neurogenesis: Regulation, implications, and potential mechanisms. Front. Neuroendocrinol. 2016, 41, 129-152. [CrossRef]

51. Galea, L.A. Gonadal hormone modulation of neurogenesis in the dentate gyrus of adult male and female rodents. Brain Res. Rev. 2008, 57, 332-341. [CrossRef] [PubMed]

52. Ponti, G.; Farinetti, A.; Marraudino, M.; Panzica, G.; Gotti, S. Sex steroids and adult neurogenesis in the ventricular-subventricular zone. Front. Endocrinol. 2018, 9, 156. [CrossRef] [PubMed]

53. Galea, L.A.; Wainwright, S.R.; Roes, M.; Duarte-Guterman, P.; Chow, C.; Hamson, D. Sex, hormones and neurogenesis in the hippocampus: Hormonal modulation of neurogenesis and potential functional implications. J. Neuroendocrinol. 2013, 25, 1039-1061. [CrossRef] [PubMed]

54. Spritzer, M.D.; Roy, E.A. Testosterone and adult neurogenesis. Biomolecules 2020, 10, 225. [CrossRef]

55. Mirescu, C.; Gould, E. Stress and adult neurogenesis. Hippocampus 2006, 16, 233-238. [CrossRef]

56. Lucassen, P.J.; Oomen, C.A.; Naninck, E.F.; Fitzsimons, C.P.; van Dam, A.-M.; Czeh, B.; Korosi, A. Regulation of adult neurogenesis and plasticity by (early) stress, glucocorticoids, and inflammation. Cold Spring Harb. Perspect. Biol. 2015, 7, a021303. [CrossRef]

57. Lucassen, P.J.; Meerlo, P.; Naylor, A.S.; van Dam, A.M.; Dayer, A.G.; Fuchs, E.; Oomen, C.A.; Czeh, B. Regulation of adult neurogenesis by stress, sleep disruption, exercise and inflammation: Implications for depression and antidepressant action. Eur. Neuropsychopharmacol. 2010, 20, 1-17. [CrossRef]

58. van Praag, H.; Kempermann, G.; Gage, F.H. Running increases cell proliferation and neurogenesis in the adult mouse dentate gyrus. Nat. Neurosci. 1999, 2, 266-270. [CrossRef]

59. Wang, C.; Alexander, G.; Berman, N.; Salehian, B.; Davidson, T.; McDonald, V.; Steiner, B.; Hull, L.; Callegari, C.; Swerdloff, R.S. Testosterone replacement therapy improves mood in hypogonadal men-a clinical research center study. J. Clin. Endocrinol. Metab. 1996, 81, 3578-3583. 
60. Wolf, O.T.; Kirschbaum, C. Endogenous estradiol and testosterone levels are associated with cognitive performance in older women and men. Horm. Behav. 2002, 41, 259-266. [CrossRef]

61. Eisenegger, C.; Haushofer, J.; Fehr, E. The role of testosterone in social interaction. Trends Cogn. Sci. 2011, 15, 263-271. [CrossRef] [PubMed]

62. Booth, A.; Granger, D.A.; Mazur, A.; Kivlighan, K.T. Testosterone and social behavior. Social Forces 2006, 85, 167-191. [CrossRef]

63. MacLusky, N.; Hajszan, T.; Prange-Kiel, J.; Leranth, C. Androgen modulation of hippocampal synaptic plasticity. Neuroscience 2006, 138, 957-965. [CrossRef]

64. Bronson, F. Climate change and seasonal reproduction in mammals. Phil. Trans. R Soc. Lond. B Biol. Sci. 2009, 364, 3331-3340. [CrossRef] [PubMed]

65. Bronson, F.; Perrigo, G. Seasonal regulation of reproduction in muroid rodents. Am. Zoologist 1987, 27, 929-940. [CrossRef]

66. Place, N.; Kenagy, G. Seasonal changes in plasma testosterone and glucocorticosteroids in free-living male yellow-pine chipmunks and the response to capture and handling. J. Comp. Physiol. B 2000, 170, 245-251. [CrossRef]

67. Schradin, C. Seasonal changes in testosterone and corticosterone levels in four social classes of a desert dwelling sociable rodent. Horm. Behav. 2008, 53, 573-579. [CrossRef]

68. Dark, J.; Zucker, I.; Wade, G.N. Photoperiodic regulation of body mass, food intake, and reproduction in meadow voles. Am. J. Physiol. 1983, 245, R334-R338. [CrossRef]

69. Spritzer, M.D.; Panning, A.W.; Engelman, S.M.; Prince, W.T.; Casler, A.E.; Georgakas, J.E.; Jaeger, E.C.; Nelson, L.R.; Roy, E.A.; Wagner, B.A. Seasonal and sex differences in cell proliferation, neurogenesis, and cell death within the dentate gyrus of adult wild-caught meadow voles. Neuroscience 2017, 360, 155-165. [CrossRef]

70. Galea, L.A.; McEwen, B.S. Sex and seasonal differences in the rate of cell proliferation in the dentate gyrus of adult wild meadow voles. Neuroscience 1999, 89, 955-964. [CrossRef]

71. Kuhn, H.G.; Dickinson-Anson, H.; Gage, F.H. Neurogenesis in the dentate gyrus of the adult rat: Age-related decrease of neuronal progenitor proliferation. J. Neurosci. 1996, 16, 2027-2033. [CrossRef]

72. Amrein, I.; Isler, K.; Lipp, H.P. Comparing adult hippocampal neurogenesis in mammalian species and orders: Influence of chronological age and life history stage. Eur. J. Neurosci. 2011, 34, 978-987. [CrossRef]

73. Leuner, B.; Kozorovitskiy, Y.; Gross, C.G.; Gould, E. Diminished adult neurogenesis in the marmoset brain precedes old age. Proc. Natl. Acad. Sci. USA 2007, 104, 17169-17173. [CrossRef]

74. Romero, L.M.; Meister, C.J.; Cyr, N.E.; Kenagy, G.; Wingfield, J.C. Seasonal glucocorticoid responses to capture in wild free-living mammals. Am. J. Physiol. Regul. Integr. Comp. Physiol. 2008, 294, R614-R622. [CrossRef]

75. Leuner, B.; Glasper, E.R.; Gould, E. Sexual experience promotes adult neurogenesis in the hippocampus despite an initial elevation in stress hormones. PLoS ONE 2010, 5, e11597. [CrossRef]

76. Glasper, E.R.; Gould, E. Sexual experience restores age-related decline in adult neurogenesis and hippocampal function. Hippocampus 2013, 23, 303-312. [CrossRef]

77. Portillo, W.; Unda, N.; Camacho, F.J.; Sanchez, M.; Corona, R.; Arzate, D.M.; Diaz, N.F.; Paredes, R.G. Sexual activity increases the number of newborn cells in the accessory olfactory bulb of male rats. Front. Neuroanat. 2012, 6, 1-9. [CrossRef]

78. Unda, N.M.; Portillo, W.; Corona, R.; Paredes, R.G. Sexual stimulation increases the survival of new cells in the accessory olfactory bulb of the male rat. Front. Neurosci. 2016, 10, 65. [CrossRef]

79. Velazco-Mendoza, M.; Camacho, F.; Paredes, R.; Portillo, W. The first mating experience induces new neurons in the olfactory bulb in male mice. Neuroscience 2019, 396, 166-174. [CrossRef]

80. Kim, J.-I.; Lee, J.W.; Lee, Y.A.; Lee, D.-H.; Han, N.S.; Choi, Y.-K.; Hwang, B.R.; Kim, H.J.; Han, J.S. Sexual activity counteracts the suppressive effects of chronic stress on adult hippocampal neurogenesis and recognition memory. Brain Res. 2013, 1538, 26-40. [CrossRef]

81. Spritzer, M.D.; Galea, L.A. Testosterone and dihydrotestosterone, but not estradiol, enhance survival of new hippocampal neurons in adult male rats. Dev. Neurobiol. 2007, 67, 1321-1333. [CrossRef] 
82. Wainwright, S.R.; Lieblich, S.E.; Galea, L.A. Hypogonadism predisposes males to the development of behavioural and neuroplastic depressive phenotypes. Psychoneuroendocrinology 2011, 36, 1327-1341. [CrossRef]

83. Spritzer, M.D.; Ibler, E.; Inglis, W.; Curtis, M.G. Testosterone and social isolation influence adult neurogenesis in the dentate gyrus of male rats. Neuroscience 2011, 195, 180-190. [CrossRef]

84. Benice, T.S.; Raber, J. Castration and training in a spatial task alter the number of immature neurons in the hippocampus of male mice. Brain Res. 2010, 1329, 21-29. [CrossRef]

85. Tzeng, W.-Y.; Chen, L.-H.; Cherng, C.G.; Tsai, Y.-N.; Yu, L. Sex differences and the modulating effects of gonadal hormones on basal and the stressor-decreased newly proliferative cells and neuroblasts in dentate gyrus. Psychoneuroendocrinology 2014, 42, 24-37. [CrossRef]

86. Fowler, C.D.; Freeman, M.E.; Wang, Z. Newly proliferated cells in the adult male amygdala are affected by gonadal steroid hormones. J. Neurobiol. 2003, 57, 257-269. [CrossRef]

87. Ormerod, B.K.; Lee, T.T.; Galea, L.A. Estradiol enhances neurogenesis in the dentate gyri of adult male meadow voles by increasing the survival of young granule neurons. Neuroscience 2004, 128, 645-654. [CrossRef]

88. Carrier, N.; Kabbaj, M. Extracellular signal-regulated kinase 2 signaling in the hippocampal dentate gyrus mediates the antidepressant effects of testosterone. Biol. Psychiatry 2012, 71, 642-651. [CrossRef]

89. Wainwright, S.R.; Workman, J.L.; Tehrani, A.; Hamson, D.K.; Chow, C.; Lieblich, S.E.; Galea, L.A. Testosterone has antidepressant-like efficacy and facilitates imipramine-induced neuroplasticity in male rats exposed to chronic unpredictable stress. Horm. Behav. 2016, 79, 58-69. [CrossRef]

90. Barker, J.M.; Galea, L.A. Repeated estradiol administration alters different aspects of neurogenesis and cell death in the hippocampus of female, but not male, rats. Neuroscience 2008, 152, 888-902. [CrossRef]

91. Duarte-Guterman, P.; Hamson, D.; Wainwright, S.; Chow, C.; Chaiton, J.; Lieblich, S.E.; Watson, N.V.; Galea, L.A. Androgens enhance adult hippocampal neurogenesis in males but not females in an age-dependent manner. Endocrinology 2019, 539296. [CrossRef]

92. Bonilla-Jaime, H.; Vazquez-Palacios, G.; Arteaga-Silva, M.; Retana-Marquez, S. Hormonal responses to different sexually related conditions in male rats. Horm. Behav. 2006, 49, 376-382. [CrossRef]

93. Kamel, F.; Wright, W.W.; Mock, E.J.; Frankel, A.I. The influence of mating and related stimuli on plasma levels of luteinizing hormone, follicle stimulating hormone, prolactin, and testosterone in the male rat. Endocrinology 1977, 101, 421-429. [CrossRef] [PubMed]

94. Pfeiffer, C.A.; Johnston, R.E. Socially stimulated androgen surges in male hamsters: The roles of vaginal secretions, behavioral interactions, and housing conditions. Horm. Behav. 1992, 26, 283-293. [CrossRef]

95. Shulman, L.M.; Spritzer, M.D. Changes in the sexual behavior and testosterone levels of male rats in response to daily interactions with estrus females. Physiol. Behav. 2014, 133, 8-13. [CrossRef]

96. Damassa, D.A.; Smith, E.R.; Tennent, B.; Davidson, J.M. The relationship between circulating testosterone levels and male sexual behavior in rats. Horm. Behav. 1977, 8, 275-286. [CrossRef]

97. Siegel, H.I. Male Sexual Behavior. In The Hamster: Reproduction and Behavior; Siegel, H.I., Ed.; Plenum Press: New York, NY, USA, 1985; pp. 191-204.

98. Wood, R.; Newman, S. Hormonal influence on neurons of the mating behavior pathway in male hamsters. In Neurobiological Effects of Sex Steroid Hormones; Micevych, P.E., Hammer, R.P., Eds.; Cambridge University Press: New York, NY, USA, 1995; pp. 3-39.

99. Celotti, F.; Melcangi, R.; Negri-Cesi, P.; Poletti, A. Testosterone metabolism in brain cells and membranes. J. Steroid Biochem. Mol. Biol. 1991, 40, 673-678. [CrossRef]

100. Estrada, M.; Uhlen, P.; Ehrlich, B.E. Ca2+ oscillations induced by testosterone enhance neurite outgrowth. J. Cell Sci. 2006, 119, 733-743. [CrossRef]

101. Estrada, M.; Varshney, A.; Ehrlich, B.E. Elevated testosterone induces apoptosis in neuronal cells. J. Biol. Chem. 2006, 281, 25492-25501. [CrossRef]

102. Park, J.H.; Takasu, N.; Alvarez, M.I.; Clark, K.; Aimaq, R.; Zucker, I. Long-term persistence of male copulatory behavior in castrated and photo-inhibited Siberian hamsters. Horm. Behav. 2004, 45, 214-221. [CrossRef]

103. Hamson, D.K.; Wainwright, S.R.; Taylor, J.; Jones, B.; Watson, N.V.; Galea, L.A. Androgens increase survival of adult-born neurons in the dentate gyrus by an androgen receptor-dependent mechanism in male rats. Endocrinology 2013, 154, 3294-3304. [CrossRef] 
104. McEwen, B.S. Invited review: Estrogens effects on the brain: Multiple sites and molecular mechanisms. J. Appl. Physiol. 2001, 91, 2785-2801. [CrossRef]

105. Ervin, K.S.; Lymer, J.M.; Matta, R.; Clipperton-Allen, A.E.; Kavaliers, M.; Choleris, E. Estrogen involvement in social behavior in rodents: Rapid and long-term actions. Horm. Behav. 2015, 74, 53-76. [CrossRef]

106. McEwen, B.S.; Alves, S.E. Estrogen actions in the central nervous system. Endocr. Rev. 1999, 20, $279-307$. [CrossRef]

107. Woolley, C.S.; McEwen, B.S. Roles of estradiol and progesterone in regulation of hippocampal dendritic spine density during the estrous cycle in the rat. J. Comp. Neurol. 1993, 336, 293-306. [CrossRef]

108. Barha, C.K.; Galea, L.A. Influence of different estrogens on neuroplasticity and cognition in the hippocampus. Biochim. Biophys. Acta 2010, 1800, 1056-1067. [CrossRef]

109. Tanapat, P.; Hastings, N.B.; Reeves, A.J.; Gould, E. Estrogen stimulates a transient increase in the number of new neurons in the dentate gyrus of the adult female rat. J. Neurosci. 1999, 19, 5792-5801. [CrossRef]

110. Lagace, D.C.; Fischer, S.J.; Eisch, A.J. Gender and endogenous levels of estradiol do not influence adult hippocampal neurogenesis in mice. Hippocampus 2007, 17, 175-180. [CrossRef]

111. Tanapat, P.; Hastings, N.B.; Gould, E. Ovarian steroids influence cell proliferation in the dentate gyrus of the adult female rat in a dose- and time-dependent manner. J. Comp. Neurol. 2005, 481, 252-265. [CrossRef]

112. Ormerod, B.K.; Galea, L.A. Reproductive status influences cell proliferation and cell survival in the dentate gyrus of adult female meadow voles: A possible regulatory role for estradiol. Neuroscience 2001, 102, 369-379. [CrossRef]

113. Smith, M.T.; Pencea, V.; Wang, Z.; Luskin, M.B.; Insel, T.R. Increased number of BrdU-labeled neurons in the rostral migratory stream of the estrous prairie vole. Horm. Behav. 2001, 39, 11-21. [CrossRef]

114. Banasr, M.; Hery, M.; Brezun, J.M.; Daszuta, A. Serotonin mediates oestrogen stimulation of cell proliferation in the adult dentate gyrus. Eur. J. Neurosci. 2001, 14, 1417-1424. [CrossRef]

115. Green, A.D.; Galea, L.A. Adult hippocampal cell proliferation is suppressed with estrogen withdrawal after a hormone-simulated pregnancy. Horm. Behav. 2008, 54, 203-211. [CrossRef]

116. Ormerod, B.K.; Lee, T.T.; Galea, L.A. Estradiol initially enhances but subsequently suppresses (via adrenal steroids) granule cell proliferation in the dentate gyrus of adult female rats. J. Neurobiol. 2003, 55, 247-260. [CrossRef]

117. Ormerod, B.; Falconer, E.; Galea, L. N-methyl-D-aspartate receptor activity and estradiol: Separate regulation of cell proliferation in the dentate gyrus of adult female meadow vole. J. Endocrinol. 2003, 179, 155-164. [CrossRef]

118. Mazzucco, C.A.; Lieblich, S.E.; Bingham, B.I.; Williamson, M.A.; Viau, V.; Galea, L.A. Both estrogen receptor alpha and estrogen receptor beta agonists enhance cell proliferation in the dentate gyrus of adult female rats. Neuroscience 2006, 141, 1793-1800. [CrossRef]

119. Nagy, A.I.; Ormerod, B.K.; Mazzucco, C.; Galea, L.A.M. Estradiol-induced enhancement in cell proliferation is mediated through estrogen receptors in the dentate gyrus of adult female rats. Drug Dev. Res. 2006, 66, 142-149. [CrossRef]

120. Barha, C.; Lieblich, S.; Galea, L. Different forms of oestrogen rapidly upregulate cell proliferation in the dentate gyrus of adult female rats. J. Neuroendocrinol. 2009, 21, 155-166. [CrossRef]

121. Clark, J.A.; Alves, S.; Gundlah, C.; Rocha, B.; Birzin, E.T.; Cai, S.J.; Flick, R.; Hayes, E.; Ho, K.; Warrier, S.; et al. Selective estrogen receptor-beta (SERM-beta) compounds modulate raphe nuclei tryptophan hydroxylase-1 (TPH-1) mRNA expression and cause antidepressant-like effects in the forced swim test. Neuropharmacology 2012, 63, 1051-1063. [CrossRef]

122. Brock, O.; Keller, M.; Veyrac, A.; Douhard, Q.; Bakker, J. Short term treatment with estradiol decreases the rate of newly generated cells in the subventricular zone and main olfactory bulb of adult female mice. Neuroscience 2010, 166, 368-376. [CrossRef]

123. Hoyk, Z.; Varga, C.; Parducz, A. Estrogen-induced region specific decrease in the density of 5-bromo-2-deoxyuridine-labeled cells in the olfactory bulb of adult female rats. Neuroscience 2006, 141, 1919-1924. [CrossRef] [PubMed]

124. Fowler, C.D.; Johnson, F.; Wang, Z. Estrogen regulation of cell proliferation and distribution of estrogen receptor-alpha in the brains of adult female prairie and meadow voles. J. Comp. Neurol. 2005, 489, 166-179. [CrossRef] [PubMed] 
125. McClure, R.E.; Barha, C.K.; Galea, L.A. $17 \beta$-Estradiol, but not estrone, increases the survival and activation of new neurons in the hippocampus in response to spatial memory in adult female rats. Horm. Behav. 2013, 63, 144-157. [CrossRef] [PubMed]

126. Chan, M.; Chow, C.; Hamson, D.K.; Lieblich, S.E.; Galea, L.A. Effects of chronic oestradiol, progesterone and medroxyprogesterone acetate on hippocampal neurogenesis and adrenal mass in adult female rats. J. Neuroendocrionol. 2014, 26, 386-399. [CrossRef]

127. Bless, E.; Reddy, T.; Acharya, K.D.; Beltz, B.; Tetel, M. Oestradiol and diet modulate energy homeostasis and hypothalamic neurogenesis in the adult female mouse. J. Neuroendocrinol. 2014, 26, 805-816. [CrossRef]

128. Clulow, F.; Mallory, F. Oestrus and induced ovulation in the meadow vole, Microtus pennsylvanicus. Reproduction 1970, 23, 341-343. [CrossRef]

129. Lee, C.; Horvath, D.; Metcalfe, R.; Inskeep, E. Ovulation in Microtus pennsylvanicus in a laboratory environment. Lab. Anim. Care 1970, 20, 1098-1102.

130. Dluzen, D.E.; Carter, C.S. Ovarian hormones regulating sexual and social behaviors in female prairie voles, Microtus ochrogaster. Physiol. Behav. 1979, 23, 597-600. [CrossRef]

131. Lim, M.M.; Wang, Z.; Olazabal, D.E.; Ren, X.; Terwilliger, E.F.; Young, L.J. Enhanced partner preference in a promiscuous species by manipulating the expression of a single gene. Nature 2004, 429, 754-757. [CrossRef]

132. Getz, L.L.; Carter, C.S.; Gavish, L. The mating system of the prairie vole Microtus ochrogaster: Field and laboratory evidence for pair-bonding. Behav. Biol. Sociobiol. 1981, 8, 189-194. [CrossRef]

133. Boonstra, R.; Boag, P. Spring declines in Microtus pennsylvanicus and the role of steroid hormones. J. Anim. Ecol. 1992, 339-352. [CrossRef]

134. Rosenblatt, J.S.; Mayer, A.D.; Giordano, A.L. Hormonal basis during pregnancy for the onset of maternal behavior in the rat. Psychoneuroendocrinology 1988, 13, 29-46. [CrossRef]

135. Chakraborty, T.R.; Gore, A.C. Aging-related changes in ovarian hormones, their receptors, and neuroendocrine function. Exp. Biol. Med. 2004, 229, 977-987. [CrossRef] [PubMed]

136. Furuta, M.; Bridges, R.S. Gestation-induced cell proliferation in the rat brain. Brain Res. Dev. Brain Res. 2005, 156, 61-66. [CrossRef] [PubMed]

137. Leuner, B.; Sabihi, S. The birth of new neurons in the maternal brain: Hormonal regulation and functional implications. Front. Neuroendocrinol 2016, 41 (Suppl. C), 99-113. [CrossRef]

138. Rose'Meyer, R.B.; Mellick, A.S.; Garnham, B.G.; Harrison, G.J.; Massa, H.M.; Griffiths, L.R. The measurement of adenosine and estrogen receptor expression in rat brains following ovariectomy using quantitative PCR analysis. Brain Res. Protoc 2003, 11, 9-18. [CrossRef]

139. Viau, V.; Meaney, M.J. Variations in the hypothalamic-pituitary-adrenal response to stress during the estrous cycle in the rat. Endocrinology 1991, 129, 2503-2511. [CrossRef]

140. Sohrabji, F.; Miranda, R.C.; Toran-Allerand, C.D. Estrogen differentially regulates estrogen and nerve growth factor receptor mRNAs in adult sensory neurons. J. Neurosci. 1994, 14, 459-471. [CrossRef]

141. Driowo, M.; Landgren, B.-M.; Stenström, B.; Diczfalusy, E. A comparison of the pharmacokinetic properties of three estradiol esters. Contraception 1980, 21, 415-424. [CrossRef]

142. Pavlides, C.; Kimura, A.; Magarin, A.; McEwen, B. Hippocampal homosynaptic long-term depression/ depotentiation induced by adrenal steroids. Neuroscience 1995, 68, 379-385. [CrossRef]

143. Mcewen, B.S.; Albeck, D.; Cameron, H.; Chao, H.M.; Gould, E.; Hastings, N.; Kuroda, Y.; Luine, V.; Magarinos, A.M.; Mckittrick, C.R. Stress and the brain: A paradoxical role for adrenal steroids. In Vitamins $\mathcal{E}$ Hormones; Elsevier: Amsterdam, The Netherlands, 1995; Volume 51, pp. 371-402.

144. Magariños, A.M.a.; McEwen, B. Stress-induced atrophy of apical dendrites of hippocampal CA3c neurons: Involvement of glucocorticoid secretion and excitatory amino acid receptors. Neuroscience 1995, 69, 89-98. [CrossRef]

145. Magariños, A.M.a.; McEwen, B.S.; Flügge, G.; Fuchs, E. Chronic psychosocial stress causes apical dendritic atrophy of hippocampal CA3 pyramidal neurons in subordinate tree shrews. J. Neurosci. 1996, 16, 3534-3540. [CrossRef] [PubMed]

146. Sousa, N.; Lukoyanov, N.; Madeira, M.; Almeida, O.; Paula-Barbosa, M. Reorganization of the morphology of hippocampal neurites and synapses after stress-induced damage correlates with behavioral improvement. Neuroscience 2000, 97, 253-266. [CrossRef] 
147. Fuchs, E.; Flugge, G.; Ohl, F.; Lucassen, P.; Vollmann-Honsdorf, G.K.; Michaelis, T. Psychosocial stress, glucocorticoids, and structural alterations in the tree shrew hippocampus. Physiol. Behav. 2001, 73, 285-291. [CrossRef]

148. Vyas, A.; Mitra, R.; Rao, B.S.; Chattarji, S. Chronic stress induces contrasting patterns of dendritic remodeling in hippocampal and amygdaloid neurons. J. Neurosci. 2002, 22, 6810-6818. [CrossRef]

149. Bennur, S.; Rao, B.S.; Pawlak, R.; Strickland, S.; McEwen, B.; Chattarji, S. Stress-induced spine loss in the medial amygdala is mediated by tissue-plasminogen activator. Neuroscience 2007, 144, 8-16. [CrossRef]

150. Radley, J.; Sisti, H.; Hao, J.; Rocher, A.B.; McCall, T.; Hof, P.; McEwen, B.; Morrison, J. Chronic behavioral stress induces apical dendritic reorganization in pyramidal neurons of the medial prefrontal cortex. Neuroscience 2004, 125, 1-6. [CrossRef]

151. Radley, J.J.; Rocher, A.B.; Janssen, W.G.; Hof, P.R.; McEwen, B.S.; Morrison, J.H. Reversibility of apical dendritic retraction in the rat medial prefrontal cortex following repeated stress. Exp. Neurol. 2005, 196, 199-203. [CrossRef]

152. Radley, J.J.; Rocher, A.B.; Rodriguez, A.; Ehlenberger, D.B.; Dammann, M.; McEwen, B.S.; Morrison, J.H.; Wearne, S.L.; Hof, P.R. Repeated stress alters dendritic spine morphology in the rat medial prefrontal cortex. J. Comp. Neurol. 2008, 507, 1141-1150. [CrossRef]

153. Schoenfeld, T.J.; Gould, E. Stress, stress hormones, and adult neurogenesis. Exp. Neurol. 2012, $233,12-21$. [CrossRef]

154. Wong, E.Y.; Herbert, J. The corticoid environment: A determining factor for neural progenitors' survival in the adult hippocampus. Eur. J. Neurosci. 2004, 20, 2491-2498. [CrossRef] [PubMed]

155. Wong, E.; Herbert, J. Raised circulating corticosterone inhibits neuronal differentiation of progenitor cells in the adult hippocampus. Neuroscience 2006, 137, 83-92. [CrossRef] [PubMed]

156. Brummelte, S.; Galea, L.A. Chronic high corticosterone reduces neurogenesis in the dentate gyrus of adult male and female rats. Neuroscience 2010, 168, 680-690. [CrossRef] [PubMed]

157. Ambrogini, P.; Orsini, L.; Mancini, C.; Ferri, P.; Barbanti, I.; Cuppini, R. Persistently high corticosterone levels but not normal circadian fluctuations of the hormone affect cell proliferation in the adult rat dentate gyrus. Neuroendocrinology 2002, 76, 366-372. [CrossRef]

158. Chetty, S.; Friedman, A.R.; Taravosh-Lahn, K.; Kirby, E.D.; Mirescu, C.; Guo, F.; Krupik, D.; Nicholas, A.; Geraghty, A.; Krishnamurthy, A. Stress and glucocorticoids promote oligodendrogenesis in the adult hippocampus. Mol. Psychiatry 2014, 19, 1275-1283. [CrossRef]

159. Murray, F.; Smith, D.W.; Hutson, P.H. Chronic low dose corticosterone exposure decreased hippocampal cell proliferation, volume and induced anxiety and depression like behaviours in mice. Eur. J. Pharmacol. 2008, 583, 115-127. [CrossRef]

160. Kim, J.B.; Ju, J.Y.; Kim, J.H.; Kim, T.-Y.; Yang, B.-H.; Lee, Y.-S.; Son, H. Dexamethasone inhibits proliferation of adult hippocampal neurogenesis in vivo and in vitro. Brain Res. 2004, 1027, 1-10. [CrossRef]

161. Gould, E.; Cameron, H.A.; Daniels, D.C.; Woolley, C.S.; McEwen, B.S. Adrenal hormones suppress cell division in the adult rat dentate gyrus. J. Neurosci. 1992, 12, 3642-3650. [CrossRef]

162. Cameron, H.A.; Gould, E. Adult neurogenesis is regulated by adrenal steroids in the dentate gyrus. Neuroscience 1994, 61, 203-209. [CrossRef]

163. Cameron, H.A.; McKay, R.D. Restoring production of hippocampal neurons in old age. Nat. Neurosci. 1999, 2, 894-897. [CrossRef]

164. Tanapat, P.; Hastings, N.B.; Rydel, T.A.; Galea, L.A.; Gould, E. Exposure to fox odor inhibits cell proliferation in the hippocampus of adult rats via an adrenal hormone-dependent mechanism. J. Comp. Neurol. 2001, 437, 496-504. [CrossRef] [PubMed]

165. Alonso, R.; Griebel, G.; Pavone, G.; Stemmelin, J.; Le Fur, G.; Soubrie, P. Blockade of CRF 1 or V $1 b$ receptors reverses stress-induced suppression of neurogenesis in a mouse model of depression. Mol. Psychiatry 2004, 9, 278. [CrossRef] [PubMed]

166. Oomen, C.A.; Mayer, J.L.; de Kloet, E.R.; Joels, M.; Lucassen, P.J. Brief treatment with the glucocorticoid receptor antagonist mifepristone normalizes the reduction in neurogenesis after chronic stress. Eur. J. Neurosci. 2007, 26, 3395-3401. [CrossRef] [PubMed]

167. Mayer, J.; Klumpers, L.; Maslam, S.; De Kloet, E.; Joels, M.; Lucassen, P. Brief treatment with the glucocorticoid receptor antagonist mifepristone normalises the corticosterone-induced reduction of adult hippocampal neurogenesis. J. Neuroendocrinol. 2006, 18, 629-631. [CrossRef] 
168. Cherng, C.G.; Lin, P.S.; Chuang, J.Y.; Chang, W.T.; Lee, Y.S.; Kao, G.S.; Lai, Y.T.; Yu, L. Presence of conspecifics and their odor-impregnated objects reverse stress-decreased neurogenesis in mouse dentate gyrus. J. Neurochem. 2010, 112, 1138-1146. [CrossRef]

169. Cherng, C.-F.G.; Chang, C.P.; Su, C.-C.; Tzeng, W.-Y.; Chuang, J.-Y.; Chen, L.-H.; Lin, K.-Y.; Yu, L. Odors from proximal species reverse the stress-decreased neurogenesis via main olfactory processing. Behav. Brain Res. 2012, 229, 106-112. [CrossRef]

170. Heine, V.M.; Maslam, S.; Zareno, J.; Joëls, M.; Lucassen, P.J. Suppressed proliferation and apoptotic changes in the rat dentate gyrus after acute and chronic stress are reversible. Eur. J. Neurosci. 2004, 19, 131-144. [CrossRef]

171. Shors, T.J.; Mathew, J.; Sisti, H.M.; Edgecomb, C.; Beckoff, S.; Dalla, C. Neurogenesis and helplessness are mediated by controllability in males but not in females. Biol. Psychiatry 2007, 62, 487-495. [CrossRef]

172. Malberg, J.E.; Duman, R.S. Cell proliferation in adult hippocampus is decreased by inescapable stress: Reversal by fluoxetine treatment. Neuropsychopharmacology 2003, 28, 1562-1571. [CrossRef]

173. Vollmayr, B.; Simonis, C.; Weber, S.; Gass, P.; Henn, F. Reduced cell proliferation in the dentate gyrusis not correlated with the development of learned helplessness. Biol. Psychiatry 2003, 54, 1035-1040. [CrossRef]

174. Bland, S.T.; Schmid, M.J.; Greenwood, B.N.; Watkins, L.R.; Maier, S.F. Behavioral control of the stressor modulates stress-induced changes in neurogenesis and fibroblast growth factor-2. Neuroreport 2006, 17, 593-597. [CrossRef]

175. Gould, E.; McEwen, B.S.; Tanapat, P.; Galea, L.A.; Fuchs, E. Neurogenesis in the dentate gyrus of the adult tree shrew is regulated by psychosocial stress and NMDA receptor activation. J. Neurosci. 1997, 17, 2492-2498. [CrossRef]

176. Falconer, E.M.; Galea, L.A. Sex differences in cell proliferation, cell death and defensive behavior following acute predator odor stress in adult rats. Brain Res. 2003, 975, 22-36. [CrossRef]

177. Holmes, M.M.; Galea, L.A. Defensive behavior and hippocampal cell proliferation: Differential modulation by naltrexone during stress. Behav. Neurosci. 2002, 116, 160-168. [CrossRef] [PubMed]

178. Pham, K.; Nacher, J.; Hof, P.R.; McEwen, B.S. Repeated restraint stress suppresses neurogenesis and induces biphasic PSA-NCAM expression in the adult rat dentate gyrus. Eur. J. Neurosci. 2003, 17, 879-886. [CrossRef] [PubMed]

179. Veenema, A.H.; de Kloet, E.R.; de Wilde, M.C.; Roelofs, A.J.; Kawata, M.; Buwalda, B.; Neumann, I.D.; Koolhaas, J.M.; Lucassen, P.J. Differential effects of stress on adult hippocampal cell proliferation in low and high aggressive mice. J. Neuroendocrinol. 2007, 19, 489-498. [CrossRef] [PubMed]

180. Bain, M.J.; Dwyer, S.M.; Rusak, B. Restraint stress affects hippocampal cell proliferation differently in rats and mice. Neurosci. Lett. 2004, 368, 7-10. [CrossRef]

181. Tzeng, W.-Y.; Wu, H.-H.; Wang, C.-Y.; Chen, J.-C.; Yu, L.; Cherng, C.G. Sex differences in stress and group housing effects on the number of newly proliferated cells and neuroblasts in middle-aged dentate gyrus. Front. Behav. Neurosci. 2017, 10, 249. [CrossRef]

182. Luo, C.; Xu, H.; Li, X.-M. Quetiapine reverses the suppression of hippocampal neurogenesis caused by repeated restraint stress. Brain Res. 2005, 1063, 32-39. [CrossRef]

183. Yap, J.J.; Takase, L.F.; Kochman, L.J.; Fornal, C.A.; Miczek, K.A.; Jacobs, B.L. Repeated brief social defeat episodes in mice: Effects on cell proliferation in the dentate gyrus. Behav. Brain Res. 2006, 172, 344-350. [CrossRef]

184. Mitra, R.; Sundlass, K.; Parker, K.J.; Schatzberg, A.F.; Lyons, D.M. Social stress-related behavior affects hippocampal cell proliferation in mice. Physiol. Behav. 2006, 89, 123-127. [CrossRef] [PubMed]

185. Buwalda, B.; van der Borght, K.; Koolhaas, J.M.; McEwen, B.S. Testosterone decrease does not play a major role in the suppression of hippocampal cell proliferation following social defeat stress in rats. Physiol. Behav. 2010, 101, 719-725. [CrossRef] [PubMed]

186. Rosenbrock, H.; Koros, E.; Bloching, A.; Podhorna, J.; Borsini, F. Effect of chronic intermittent restraint stress on hippocampal expression of marker proteins for synaptic plasticity and progenitor cell proliferation in rats. Brain Res. 2005, 1040, 55-63. [CrossRef] [PubMed]

187. Hulshof, H.J.; Novati, A.; Luiten, P.G.; den Boer, J.A.; Meerlo, P. Despite higher glucocorticoid levels and stress responses in female rats, both sexes exhibit similar stress-induced changes in hippocampal neurogenesis. Behav. Brain Res. 2012, 234, 357-364. [CrossRef] [PubMed] 
188. Westenbroek, C.; Den Boer, J.A.; Veenhuis, M.; Ter Horst, G.J. Chronic stress and social housing differentially affect neurogenesis in male and female rats. Brain Res. Bull. 2004, 64, 303-308. [CrossRef]

189. Jayatissa, M.N.; Bisgaard, C.; Tingström, A.; Papp, M.; Wiborg, O. Hippocampal cytogenesis correlates to escitalopram-mediated recovery in a chronic mild stress rat model of depression. Neuropsychopharmacology 2006, 31, 2395-2404. [CrossRef]

190. Surget, A.; Tanti, A.; Leonardo, E.; Laugeray, A.; Rainer, Q.; Touma, C.; Palme, R.; Griebel, G.; Ibarguen-Vargas, Y.; Hen, R. Antidepressants recruit new neurons to improve stress response regulation. Mol. Psychiatry 2011, 16, 1177-1188. [CrossRef]

191. Czeh, B.; Welt, T.; Fischer, A.K.; Erhardt, A.; Schmitt, W.; Muller, M.B.; Toschi, N.; Fuchs, E.; Keck, M.E. Chronic psychosocial stress and concomitant repetitive transcranial magnetic stimulation: Effects on stress hormone levels and adult hippocampal neurogenesis. Biol. Psychiatry 2002, 52, 1057-1065. [CrossRef]

192. Czeh, B.; Muller-Keuker, J.I.; Rygula, R.; Abumaria, N.; Hiemke, C.; Domenici, E.; Fuchs, E. Chronic social stress inhibits cell proliferation in the adult medial prefrontal cortex: Hemispheric asymmetry and reversal by fluoxetine treatment. Neuropsychopharmacology 2007, 32, 1490-1503. [CrossRef]

193. Czeh, B.; Michaelis, T.; Watanabe, T.; Frahm, J.; de Biurrun, G.; van Kampen, M.; Bartolomucci, A.; Fuchs, E. Stress-induced changes in cerebral metabolites, hippocampal volume, and cell proliferation are prevented by antidepressant treatment with tianeptine. Proc. Natl. Acad. Sci. USA 2001, 98, 12796-12801. [CrossRef]

194. Simon, M.; Czeh, B.; Fuchs, E. Age-dependent susceptibility of adult hippocampal cell proliferation to chronic psychosocial stress. Brain Res. 2005, 1049, 244-248. [CrossRef] [PubMed]

195. Lieberwirth, C.; Liu, Y.; Jia, X.; Wang, Z. Social isolation impairs adult neurogenesis in the limbic system and alters behaviors in female prairie voles. Horm. Behav. 2012, 62, 357-366. [CrossRef] [PubMed]

196. Lehmann, M.L.; Brachman, R.A.; Martinowich, K.; Schloesser, R.J.; Herkenham, M. Glucocorticoids orchestrate divergent effects on mood through adult neurogenesis. J. Neurosci. 2013, 33, 2961-2972. [CrossRef] [PubMed]

197. Fornal, C.A.; Stevens, J.; Barson, J.R.; Blakley, G.G.; Patterson-Buckendahl, P.; Jacobs, B.L. Delayed suppression of hippocampal cell proliferation in rats following inescapable shocks. Brain Res. 2007, 1130, 48-53. [CrossRef] [PubMed]

198. Dagyte, G.; Van der Zee, E.A.; Postema, F.; Luiten, P.G.; Den Boer, J.A.; Trentani, A.; Meerlo, P. Chronic but not acute foot-shock stress leads to temporary suppression of cell proliferation in rat hippocampus. Neuroscience 2009, 162, 904-913. [CrossRef] [PubMed]

199. Thomas, R.M.; Urban, J.H.; Peterson, D.A. Acute exposure to predator odor elicits a robust increase in corticosterone and a decrease in activity without altering proliferation in the adult rat hippocampus. Exp. Neurol. 2006, 201, 308-315. [CrossRef]

200. Thomas, R.M.; Hotsenpiller, G.; Peterson, D.A. Acute psychosocial stress reduces cell survival in adult hippocampal neurogenesis without altering proliferation. J. Neurosci. 2007, 27, 2734-2743. [CrossRef]

201. Tsuda, A.; Tanaka, M. Differential changes in noradrenaline turnover in specific regions of rat brain produced by controllable and uncontrollable shocks. Behav. Neurosci. 1985, 99, 802. [CrossRef]

202. Shors, T.J.; Seib, T.B.; Levine, S.; Thompson, R.F. Inescapable versus escapable shock modulates long-term potentiation in the rat hippocampus. Science 1989, 244, 224-226. [CrossRef]

203. Parihar, V.K.; Hattiangady, B.; Kuruba, R.; Shuai, B.; Shetty, A.K. Predictable chronic mild stress improves mood, hippocampal neurogenesis and memory. Mol. Psychiatry 2011, 16, 171-183. [CrossRef]

204. Pan, Y.; Li, M.; Lieberwirth, C.; Wang, Z.; Zhang, Z. Social defeat and subsequent isolation housing affect behavior as well as cell proliferation and cell survival in the brains of male greater long-tailed hamsters. Neuroscience 2014, 265 (Suppl. C), 226-237. [CrossRef] [PubMed]

205. Chen, C.-C.; Huang, C.-C.; Hsu, K.-S. Chronic social stress affects synaptic maturation of newly generated neurons in the adult mouse dentate gyrus. Int. J. Neuropsychopharmacol. 2016, 19, 1-10. [CrossRef] [PubMed]

206. Stranahan, A.M.; Khalil, D.; Gould, E. Social isolation delays the positive effects of running on adult neurogenesis. Nat. Neurosci. 2006, 9, 526-533. [CrossRef] [PubMed]

207. Galea, L.; McEwen, B.; Tanapat, P.; Deak, T.; Spencer, R.; Dhabhar, F. Sex differences in dendritic atrophy of CA3 pyramidal neurons in response to chronic restraint stress. Neuroscience 1997, 81, 689-697. [CrossRef]

208. Weiss, I.C.; Pryce, C.R.; Jongen-Relo, A.L.; Nanz-Bahr, N.I.; Feldon, J. Effect of social isolation on stress-related behavioural and neuroendocrine state in the rat. Behav. Brain Res. 2004, 152, 279-295. [CrossRef]

209. Pluchino, N.; Russo, M.; Santoro, A.; Litta, P.; Cela, V.; Genazzani, A. Steroid hormones and BDNF. Neuroscience 2013, 239, 271-279. [CrossRef] 
210. Murer, M.; Yan, Q.; Raisman-Vozari, R. Brain-derived neurotrophic factor in the control human brain, and in Alzheimer's disease and Parkinson's disease. Prog. Neurobiol. 2001, 63, 71-124. [CrossRef]

211. Bernd, P. The role of neurotrophins during early development. Gene Expr. 2008, 14, 241-250. [CrossRef]

212. Bibel, M.; Barde, Y.-A. Neurotrophins: Key regulators of cell fate and cell shape in the vertebrate nervous system. Genes Dev. 2000, 14, 2919-2937. [CrossRef]

213. Lipsky, R.H.; Marini, A.M. Brain-derived neurotrophic factor in neuronal survival and behavior-related plasticity. Ann. N.Y. Acad. Sci. 2007, 1122, 130-143. [CrossRef]

214. Poo, M.-m. Neurotrophins as synaptic modulators. Nat. Rev. Neurosci. 2001, 2, 24-32. [CrossRef] [PubMed]

215. Minichiello, L. TrkB signalling pathways in LTP and learning. Nat. Rev. Neurosci. 2009, 10, 850-860. [CrossRef] [PubMed]

216. Yoshii, A.; Constantine-Paton, M. Postsynaptic BDNF-TrkB signaling in synapse maturation, plasticity, and disease. Dev. Neurobiol. 2010, 70, 304-322. [CrossRef] [PubMed]

217. McAllister, A.K.; Lo, D.C.; Katz, L.C. Neurotrophins regulate dendritic growth in developing visual cortex. Neuron 1995, 15, 791-803. [CrossRef]

218. McAllister, A.K.; Katz, L.C.; Lo, D.C. Opposing roles for endogenous BDNF and NT-3 in regulating cortical dendritic growth. Neuron 1997, 18,767-778. [CrossRef]

219. Lom, B.; Cohen-Cory, S. Brain-derived neurotrophic factor differentially regulates retinal ganglion cell dendritic and axonal arborization in vivo. J. Neurosci. 1999, 19, 9928-9938. [CrossRef]

220. Yacoubian, T.A.; Lo, D.C. Truncated and full-length TrkB receptors regulate distinct modes of dendritic growth. Nat. Neurosci. 2000, 3, 342-349. [CrossRef]

221. Horch, H.W.; Katz, L.C. BDNF release from single cells elicits local dendritic growth in nearby neurons. Nat. Neursci. 2002, 5, 1177-1184. [CrossRef]

222. Schmidt, H.D.; Duman, R.S. The role of neurotrophic factors in adult hippocampal neurogenesis, antidepressant treatments and animal models of depressive-like behavior. Behav. Pharmacol. 2007, 18, 391-418. [CrossRef]

223. Bath, K.G.; Akins, M.R.; Lee, F.S. BDNF control of adult SVZ neurogenesis. Dev. Psychobiol. 2012, 54, 578-589. [CrossRef]

224. Pencea, V.; Bingaman, K.D.; Wiegand, S.J.; Luskin, M.B. Infusion of brain-derived neurotrophic factor into the lateral ventricle of the adult rat leads to new neurons in the parenchyma of the striatum, septum, thalamus, and hypothalamus. J. Neurosci. 2001, 21, 6706-6717. [CrossRef] [PubMed]

225. Zigova, T.; Pencea, V.; Wiegand, S.J.; Luskin, M.B. Intraventricular administration of BDNF increases the number of newly generated neurons in the adult olfactory bulb. Mol. Cell. Neurosci. 1998, 11, 234-245. [CrossRef] [PubMed]

226. Scharfman, H.; Goodman, J.; Macleod, A.; Phani, S.; Antonelli, C.; Croll, S. Increased neurogenesis and the ectopic granule cells after intrahippocampal BDNF infusion in adult rats. Exp. Neurol. 2005, 192, 348-356. [CrossRef] [PubMed]

227. Castren, E.; Thoenen, H.; Lindholm, D. Brain-derived neurotrophic factor messenger RNA is expressed in the septum, hypothalamus and in adrenergic brain stem nuclei of adult rat brain and is increased by osmotic stimulation in the paraventricular nucleus. Neuroscience 1995, 64, 71-80. [CrossRef]

228. Conner, J.M.; Lauterborn, J.C.; Yan, Q.; Gall, C.M.; Varon, S. Distribution of brain-derived neurotrophic factor (BDNF) protein and mRNA in the normal adult rat CNS: Evidence for anterograde axonal transport. J. Neurosci. 1997, 17, 2295-2313. [CrossRef] [PubMed]

229. Zhou, X.F.; Song, X.Y.; Zhong, J.H.; Barati, S.; Zhou, F.H.H.; Johnson, S.M. Distribution and localization of pro-brain-derived neurotrophic factor-like immunoreactivity in the peripheral and central nervous system of the adult rat. J. Neurochem. 2004, 91, 704-715. [CrossRef] [PubMed]

230. Ayer-LeLievre, C.; Olson, L.; Ebendal, T.; Seiger, A.; Persson, H. Expression of the beta-nerve growth factor gene in hippocampal neurons. Science 1988, 240, 1339-1341. [CrossRef]

231. Scharfman, H.E.; MacLusky, N.J. Estrogen and brain-derived neurotrophic factor (BDNF) in hippocampus: Complexity of steroid hormone-growth factor interactions in the adult CNS. Front. Neuroendocrinol. 2006, 27, 415-435. [CrossRef]

232. Sohrabji, F.; Lewis, D.K. Estrogen-BDNF interactions: Implications for neurodegenerative diseases. Front. Neuroendocrinol. 2006, 27, 404-414. [CrossRef]

233. Larson, T.A. Sex steroids, adult neurogenesis, and inflammation in CNS homeostasis, degeneration, and repair. Front. Endocrionl. 2018, 9, 205. [CrossRef] 
234. Toran-Allerand, C.D.; Miranda, R.C.; Bentham, W.; Sohrabji, F.; Brown, T.J.; Hochberg, R.B.; MacLusky, n.J. Estrogen receptors colocalize with low-affinity nerve growth factor receptors in cholinergic neurons of the basal forebrain. Proc. Natl. Acad. Sci. USA 1992, 89, 4668-4672. [CrossRef] [PubMed]

235. Miranda, R.C.; Sohrabji, F.; Toran-Allerand, C.D. Presumptive estrogen target neurons express mRNAs for both the neurotrophins and neurotrophin receptors: A basis for potential developmental interactions of estrogen with the neurotrophins. Mol. Cell Neurosci. 1993, 4, 510-525. [CrossRef] [PubMed]

236. Sohrabji, F.; Miranda, R.; Toran-Allerand, C.D. Identification of a putative estrogen response element in the gene encoding brain-derived neurotrophic factor. Proc. Natl. Acad. Sci. USA 1995, 92, 11110-11114. [CrossRef] [PubMed]

237. Gibbs, R.B. Levels of trkA and BDNF mRNA, but not NGF mRNA, fluctuate across the estrous cycle and increase in response to acute hormone replacement. Brain Res. 1998, 787, 259-268. [CrossRef]

238. Cavus, I.; Duman, R.S. Influence of estradiol, stress, and 5-HT2A agonist treatment on brain-derived neurotrophic factor expression in female rats. Biol. Psychiatry 2003, 54, 59-69. [CrossRef]

239. Scharfman, H.E.; Mercurio, T.C.; Goodman, J.H.; Wilson, M.A.; MacLusky, N.J. Hippocampal excitability increases during the estrous cycle in the rat: A potential role for brain-derived neurotrophic factor. J. Neurosci. 2003, 23, 11641-11652. [CrossRef]

240. Jezierski, M.; Sohrabji, F. Region-and peptide-specific regulation of the neurotrophins by estrogen. Brain Res. Mol. Brain Res. 2000, 85, 77-84. [CrossRef]

241. Singh, M.; Meyer, E.M.; Simpkins, J.W. The effect of ovariectomy and estradiol replacement on brain-derived neurotrophic factor messenger ribonucleic acid expression in cortical and hippocampal brain regions of female Sprague-Dawley rats. Endocrinology 1995, 136, 2320-2324. [CrossRef]

242. Liu, Y.; Fowler, C.D.; Young, L.J.; Yan, Q.; Insel, T.R.; Wang, Z. Expression and estrogen regulation of brain-derived neurotrophic factor gene and protein in the forebrain of female prairie voles. J. Comp. Neurol. 2001, 433, 499-514. [CrossRef]

243. Zhou, J.; Zhang, H.; Cohen, R.S.; Pandey, S.C. Effects of estrogen treatment on expression of brain-derived neurotrophic factor and cAMP response element-binding protein expression and phosphorylation in rat amygdaloid and hippocampal structures. Neuroendocrinology 2005, 81, 294-310. [CrossRef]

244. Gibbs, R.B. Treatment with estrogen and progesterone affects relative levels of brain-derived neurotrophic factor mRNA and protein in different regions of the adult rat brain. Brain Res. 1999, 844, 20-27. [CrossRef]

245. Jezierski, M.K.; Sohrabji, F. Estrogen enhances retrograde transport of brain-derived neurotrophic factor in the rodent forebrain. Endocrionology 2003, 144, 5022-5029. [CrossRef] [PubMed]

246. Azmitia, E.C. Serotonin and brain: Evolution, neuroplasticity, and homeostasis. Int. Rev. Neurobiol. 2007, 77, 31-56.

247. Lucki, I. The spectrum of behaviors influenced by serotonin. Biol. Psychiatry 1998. [CrossRef]

248. Bacqué-Cazenave, J.; Bharatiya, R.; Barrière, G.; Delbecque, J.-P.; Bouguiyoud, N.; Di Giovanni, G.; Cattaert, D.; De Deurwaerdère, P. Serotonin in animal cognition and behavior. Int. J. Mol. Sci. 2020, 21, 1649. [CrossRef] [PubMed]

249. Djavadian, R.L. Serotonin and neurogenesis in the hippocampal dentate gyrus of adult mammals. Acta Neurobiol. Exp. 2004, 64, 189-202.

250. Jacobs, B.L.; Van Praag, H.; Gage, F. Adult brain neurogenesis and psychiatry: A novel theory of depression. Mol. Psychiatry 2000, 5, 262-269. [CrossRef]

251. Gould, E. Serotonin and hippocampal neurogenesis. Neuropsychopharmacology 1999, 21, 46S-51S. [CrossRef]

252. Alenina, N.; Klempin, F. The role of serotonin in adult hippocampal neurogenesis. Behav. Brain Res. 2015, 277, 49-57. [CrossRef]

253. Brezun, J.M.; Daszuta, A. Depletion in serotonin decreases neurogenesis in the dentate gyrus and the subventricular zone of adult rats. Neuroscience 1999, 89, 999-1002. [CrossRef]

254. Brezun, J.M.; Daszuta, A. Serotonin may stimulate granule cell proliferation in the adult hippocampus, as observed in rats grafted with foetal raphe neurons. Eur. J. Neurosci. 2000, 12, 391-396. [CrossRef] [PubMed]

255. Huang, G.-J.; Herbert, J. The role of 5-HT1A receptors in the proliferation and survival of progenitor cells in the dentate gyrus of the adult hippocampus and their regulation by corticoids. Neuroscience 2005, 135, 803-813. [CrossRef] [PubMed] 
256. Malberg, J.E.; Eisch, A.J.; Nestler, E.J.; Duman, R.S. Chronic antidepressant treatment increases neurogenesis in adult rat hippocampus. J. Neurosci. 2000, 20, 9104-9110. [CrossRef] [PubMed]

257. Banasr, M.; Hery, M.; Printemps, R.; Daszuta, A. Serotonin-induced increases in adult cell proliferation and neurogenesis are mediated through different and common 5-HT receptor subtypes in the dentate gyrus and the subventricular zone. Neuropsychopharmacology 2004, 29, 450-460. [CrossRef] [PubMed]

258. Klempin, F.; Babu, H.; De Pietri Tonel, D.; Alarcon, E.; Fabel, K.; Kempermann, G. Oppositional effects of serotonin receptors 5-HT1a, 2, and 2c in the regulation of adult hippocampal neurogenesis. Front. Mol. Neurosci. 2010, 3, 14. [CrossRef] [PubMed]

259. Radley, J.J.; Jacobs, B.L. 5-HT1A receptor antagonist administration decreases cell proliferation in the dentate gyrus. Brain Res. 2002, 955, 264-267. [CrossRef]

260. Jha, S.; Rajendran, R.; Davda, J.; Vaidya, V.A. Selective serotonin depletion does not regulate hippocampal neurogenesis in the adult rat brain: Differential effects of p-chlorophenylalanine and 5,7-dihydroxytryptamine. Brain Res. 2006, 1075, 48-59. [CrossRef]

261. Manev, H.; Uz, T.; Smalheiser, N.R.; Manev, R. Antidepressants alter cell proliferation in the adult brain in vivo and in neural cultures in vitro. Eur. J. Pharmacol. 2001, 411, 67-70. [CrossRef]

262. Santarelli, L.; Saxe, M.; Gross, C.; Surget, A.; Battaglia, F.; Dulawa, S.; Weisstaub, N.; Lee, J.; Duman, R.; Arancio, O.; et al. Requirement of hippocampal neurogenesis for the behavioral effects of antidepressants. Science 2003, 301, 805-809. [CrossRef]

263. Marcussen, A.B.; Flagstad, P.; Kristjansen, P.; Johansen, F.F.; Englund, U. Increase in neurogenesis and behavioural benefit after chronic fluoxetine treatment in Wistar rats. Acta Neurol. Scand. 2008, 117, 94-100. [CrossRef]

264. Huang, G.-J.; Herbert, J. Stimulation of neurogenesis in the hippocampus of the adult rat by fluoxetine requires rhythmic change in corticosterone. Biol. Psychiatry 2006, 59, 619-624. [CrossRef] [PubMed]

265. Wang, J.-W.; David, D.J.; Monckton, J.E.; Battaglia, F.; Hen, R. Chronic fluoxetine stimulates maturation and synaptic plasticity of adult-born hippocampal granule cells. J. Neurosci. 2008, 28, 1374-1384. [CrossRef] [PubMed]

266. Cowen, D.S.; Takase, L.F.; Fornal, C.A.; Jacobs, B.L. Age-dependent decline in hippocampal neurogenesis is not altered by chronic treatment with fluoxetine. Brain Res. 2008, 1228, 14-19. [CrossRef] [PubMed]

267. Couillard-Despres, S.; Wuertinger, C.; Kandasamy, M.; Caioni, M.; Stadler, K.; Aigner, R.; Bogdahn, U.; Aigner, L. Ageing abolishes the effects of fluoxetine on neurogenesis. Mol. Psychiatry 2009, 14, 856-864. [CrossRef] [PubMed]

268. Ohira, K.; Miyakawa, T. Chronic treatment with fluoxetine for more than 6 weeks decreases neurogenesis in the subventricular zone of adult mice. Mol. Brain 2011, 4, 10. [CrossRef]

269. Miller, B.H.; Schultz, L.E.; Gulati, A.; Cameron, M.D.; Pletcher, M.T. Genetic regulation of behavioral and neuronal responses to fluoxetine. Neuropsychopharmacology 2008, 33, 1312-1322. [CrossRef]

270. Mori, M.; Murata, Y.; Matsuo, A.; Takemoto, T.; Mine, K. Chronic treatment with the 5-HT1A receptor partial agonist tandospirone increases hippocampal neurogenesis. Neurol. Ther. 2014, 3, 67-77. [CrossRef]

271. Bethea, C.L.; Lu, N.Z.; Gundlah, C.; Streicher, J.M. Diverse actions of ovarian steroids in the serotonin neural system. Front. Neuroendocrinol. 2002, 23, 41-100. [CrossRef]

272. Gundlah, C.; Kohama, S.G.; Mirkes, S.J.; Garyfallou, V.T.; Urbanski, H.F.; Bethea, C.L. Distribution of estrogen receptor beta $(E R \beta)$ mRNA in hypothalamus, midbrain and temporal lobe of spayed macaque: Continued expression with hormone replacement. Mol. Brain Res. 2000, 76, 191-204. [CrossRef]

273. Gundlah, C.; Lu, N.Z.; Mirkes, S.J.; Bethea, C.L. Estrogen receptor beta (ER $\beta$ ) mRNA and protein in serotonin neurons of macaques. Mol. Brain Res. 2001, 91, 14-22. [CrossRef]

274. Lu, N.; Shlaes, T.; Gundlah, C.; Dziennis, S.; Lyle, R.; Bethea, C.L. Ovarian steroid action on tryptophan hydroxylase protein and serotonin compared to localization of ovarian steroid receptors in midbrain of guinea pigs. Endocrine 1999, 11, 257-267. [CrossRef]

275. Shughrue, P.J.; Komm, B.; Merchenthaler, I. The distribution of estrogen receptor- $\beta$ mRNA in the rat hypothalamus. Steroids 1996, 61, 678-681. [CrossRef]

276. Bethea, C.; Pecins-Thompson, M.; Schutzer, W.E.; Gundlah, C.; Lu, Z. Ovarian steroids and serotonin neural function. Mol. Neurobiol. 1998, 18, 87-123. [CrossRef] [PubMed] 
277. Sumner, B.E.; Fink, G. Testosterone as well as estrogen increases serotonin2A receptor mRNA and binding site densities in the male rat brain. Mol Brain Res. 1998, 59, 205-214. [CrossRef]

278. Gundlah, C.; Pecins-Thompson, M.; Schutzer, W.; Bethea, C. Ovarian steroid effects on serotonin 1A, 2A and 2C receptor mRNA in macaque hypothalamus. Mol. Brain Res. 1999, 63, 325-339. [CrossRef]

279. Birzniece, V.; Johansson, I.-M.; Wang, M.-D.; Seckl, J.R.; Bäckström, T.; Olsson, T. Serotonin 5-HT1A receptor mRNA expression in dorsal hippocampus and raphe nuclei after gonadal hormone manipulation in female rats. Neuroendocrinology 2001, 74, 135-142. [CrossRef]

280. Pecins-Thompson, M.; Brown, N.A.; Bethea, C.L. Regulation of serotonin re-uptake transporter mRNA expression by ovarian steroids in rhesus macaques. Mol. Brain Res. 1998, 53, 120-129. [CrossRef]

281. Nibuya, M.; Morinobu, S.; Duman, R.S. Regulation of BDNF and trkB mRNA in rat brain by chronic electroconvulsive seizure and antidepressant drug treatments. J. Neurosci. 1995, 15, 7539-7547. [CrossRef]

282. Vaidya, V.A.; Terwilliger, R.M.Z.; Duman, R.S. Role of 5-HT2A receptors in the stress-induced down-regulation of brain-derived neurotrophic factor expression in rat hippocampus. Neurosci. Lett. 1999, 262, 1-4. [CrossRef]

283. Lee, H.-J.; Macbeth, A.H.; Pagani, J.H.; Young 3rd, W.S. Oxytocin: Thgreat facilitator of life. Prog. Neurobiol. 2009, 88, 127-151.

284. Lieberwirth, C.; Wang, Z. Social bonding: Regulation by neuropeptides. Front. Neurosci. 2014, 8, 1-13. [CrossRef] [PubMed]

285. Insel, T.; Winslow, J.; Wang, Z.; Young, L.; Hulihan, T. Oxytocin and the molecular basis of monogamy. Adv. Exp. Med. Biol. 1995, 395, 227-234. [PubMed]

286. Kendrick, K.M.; Da Costa, A.P.C.; Broad, K.D.; Ohkura, S.; Guevara, R.; Lévy, F.; Keverne, E.B. Neural control of maternal behaviour and olfactory recognition of offspring. Brain Res. Bull. 1997, 44, 383-395. [CrossRef]

287. Pedersen, C.A.; Caldwell, J.D.; Walker, C.; Ayers, G.; Mason, G.A. Oxytocin activates the postpartum onset of rat maternal behavior in the ventral tegmental and medial preoptic areas. Behav. Neurosci. 1994, 108, 1163-1171. [CrossRef]

288. Gordon, I.; Zagoory-Sharon, O.; Leckman, J.F.; Feldman, R. Prolactin, oxytocin, and the development of paternal behavior across the first six months of fatherhood. Horm. Behav. 2010, 58, 513-518. [CrossRef]

289. Leuner, B.; Caponiti, J.M.; Gould, E. Oxytocin stimulates adult neurogenesis even under conditions of stress and elevated glucocorticoids. Hippocampus 2012, 22, 861-868. [CrossRef]

290. Simonian, S.X.; Herbison, A.E. Differential expression of estrogen receptor alpha and beta immunoreactivity by oxytocin neurons of rat paraventricular nucleus. J. Neuroendocrinol. 1997, 9, 803-806. [CrossRef]

291. Hrabovszky, E.; Kalló, I.; Steinhauser, A.; Merchenthaler, I.; Coen, C.W.; Petersen, S.L.; Liposits, Z. Estrogen receptor- $\beta$ in oxytocin and vasopressin neurons of the rat and human hypothalamus: Immunocytochemical and in situ hybridization studies. J. Comp. Neurol. 2004, 473, 315-333. [CrossRef]

292. Meddle, S.L.; Bishop, V.R.; Gkoumassi, E.; van Leeuwen, F.W.; Douglas, A.J. Dynamic changes in oxytocin receptor expression and activation at parturition in the rat brain. Endocrinology 2007, 148, 5095-5104. [CrossRef]

293. Tribollet, E.; Audigier, S.; Dubois-Dauphin, M.; Dreifuss, J.J. Gonadal steroids regulate oxytocin receptors but not vasopressin receptors in the brain of male and female rats. An autoradiographical study. Brain Res. 1990, 511, 129-140. [CrossRef]

294. Breton, C.; Zingg, H.H. Expression and region-specific regulation of the oxytocin receptor gene in rat brain. Endocrinology 1997, 138, 1857-1862. [CrossRef] [PubMed]

295. Larcher, A.; Neculcea, J.; Breton, C.; Arslan, A.; Rozen, F.; Russo, C.; Zingg, H. Oxytocin receptor gene expression in the rat uterus during pregnancy and the estrous cycle and in response to gonadal steroid treatment. Endocrinology 1995, 136, 5350-5356. [CrossRef] [PubMed]

296. Liberzon, I.; Young, E.A. Effects of stress and glucocorticoids on CNS oxytocin receptor binding. Psychoneuroendocrinology 1997, 22, 411-422. [CrossRef]

297. Chaouloff, F. Serotonin, stress and corticoids. J. Psychopharmacol. 2000, 14, 139-151. [CrossRef]

298. Suri, D.; Vaidya, V. Glucocorticoid regulation of brain-derived neurotrophic factor: Relevance to hippocampal structural and functional plasticity. Neuroscience 2013, 239, 196-213. [CrossRef] 
299. McLaughlin, K.J.; Wilson, J.O.; Harman, J.; Wright, R.L.; Wieczorek, L.; Gomez, J.; Korol, D.L.; Conrad, C.D. Chronic $17 \beta$-estradiol or cholesterol prevents stress-induced hippocampal CA3 dendritic retraction in ovariectomized female rats: Possible correspondence between CA1 spine properties and spatial acquisition. Hippocampus 2010, 20, 768-786. [CrossRef]

300. Takuma, K.; Matsuo, A.; Himeno, Y.; Hoshina, Y.; Ohno, Y.; Funatsu, Y.; Arai, S.; Kamei, H.; Mizoguchi, H.; Nagai, T. 17 $\beta$-estradiol attenuates hippocampal neuronal loss and cognitive dysfunction induced by chronic restraint stress in ovariectomized rats. Neuroscience 2007, 146, 60-68. [CrossRef]

(C) 2020 by the authors. Licensee MDPI, Basel, Switzerland. This article is an open access article distributed under the terms and conditions of the Creative Commons Attribution (CC BY) license (http://creativecommons.org/licenses/by/4.0/). 